\title{
Switch in the Expression of Rat GABA - Receptor Subtypes during Postnatal Development: An Immunohistochemical Study
}

\author{
J.-M. Fritschy, ${ }^{1}$ J. Paysan,' A. Enna, ${ }^{2}$ and H. Mohler ${ }^{1}$ \\ 'University of Zurich, Institute of Pharmacology, 8057 Zurich, Switzerland and ${ }^{2}$ Yale University, New Haven, Connecticut, \\ 06520
}

The involvement of GABA in neuronal differentiation and maturation precedes its role as inhibitory neurotransmitter in the brain. It was therefore investigated whether $\mathrm{GABA}_{\mathrm{A}}$ receptors mediating the actions of GABA in neonatal and adult brain can be distinguished by their molecular structure and cellular location. Immunohistochemistry with subunitspecific antibodies was employed to analyze changes in the distribution of GABA $\mathrm{A}_{\mathrm{A}}$-receptor subunits during postnatal development. In particular, subunit association patterns, as evidenced by colocalization of subunits within individual neurons, were analyzed by confocal laser microscopy. The subunits analyzed include the $\alpha 1$ - and $\alpha 2$-subunits, which are associated with pharmacologically distinct GABA $_{A}$-receptor subtypes, and the $\beta 2,3$-subunits, which are a major constituent of GABA receptors in both immature and adult rat brain. Each of these subunits exhibited age-dependent changes in their distribution, indicative of a differential maturation process. The $\alpha 1$-subunit immunoreactivity (-IR) was low at birth, restricted to a few areas, and increased dramatically during the first postnatal weeks. By contrast, the $\alpha 2-s u b u n i t-I R$ displayed a widespread distribution throughout the brain at birth, and disappeared from numerous areas soon after the appearance of the $\alpha 1$-subunit. Double-immunofluorescence staining demonstrated the coexistence of both subunits in many individual neurons during a short time window, indicating that receptors containing the $\alpha 1$ subunit gradually replace receptors containing the $\alpha 2$-subunit in these cells. Staining for the $\beta 2,3-$ subunits was prominent and ubiquitous at every developmental age, indicating that these subunits are present in both neonatal and adult GABA $_{A}$ receptors. Indeed, double-immunofluorescence staining revealed an extensive colocalization of the $\alpha 2-$ and $\beta 2,3-$ subunits in neurons from neonatal rats, whereas the $\beta 2,3$-subunits were associated with the $\alpha 1$-subunit at later stages. Thus, the onset of $\alpha 1$-subunit staining in maturing brain is indicative for the expression of a new, prevalent receptor subtype, presumably involved in synaptic inhibition. These findings demonstrate a switch in the subunit composition of $\mathrm{GABA}_{\mathrm{A}}$ receptors during postnatal development,

\footnotetext{
Received Oct. 4, 1993; revised Feb. 8, 1994; accepted Mar. 10, 1994.

We are grateful to Francoise Uldry for technical assistance, Manuela Scliweingruber for secretarial help and Romy Gisler for photography. This work was supported by the Swiss National Science Foundation Grant NF 31-25688.88 and NF 31-27809.89.

Correspondence should be addressed to Dr. Jean-Marc Fritschy, Institute of Pharmacology, University of Zurich, Winterthurerstrasse 190, CH-8057 Zurich, Switzerland.

Copyright (C) 1994 Society for Neuroscience $0270-6474 / 94 / 145302-23 \$ 05.00 / 0$
}

suggesting the existence of molecularly distinct immature and adult forms of $\mathrm{GABA}_{\mathrm{A}}$ receptors in rat CNS.

[Key words: GABA, inhibitory neurotransmission, benzodiazepine receptor, brain maturation, synaptogenesis]

Although GABA is the major inhibitory neurotransmitter in the adult brain, it is expressed early in fetal life, well before the onset of synaptogenesis (Lauder et al., 1986; Van Eden et al., 1989; Cobas et al., 1991; Ma et al., 1992; Fiszman et al., 1993), being present in both neurons and fiber tracts (Lauder et al., 1986) and released from growth cones in vivo (Taylor and Gordon-Weeks, 1989; Taylor et al., 1990). GABA receptors are also abundant in the prenatal brain, as demonstrated autoradiographically by the existence of benzodiazepine radioligand binding sites (Schlumpf et al., 1983; Shaw et al., 1991), histochemically by the expression of subunit mRNAs (MacLennan et al., 1991; Zhang et al., 1991; Laurie et al., 1992; Poulter et al., 1992, 1993) and receptor epitopes (Huntley et al., 1990; Cobas et al., 1991; Meinecke and Rakic, 1992), and biochemically by the GABA-dependent gating of chloride channels (Kellogg and Pleger, 1989). A neurotrophic role has been proposed for GABA (Chronwall and Wolff, 1980; Lauder et al., 1986; Ma et al., 1992; Behar et al., 1993) based on its ability to modulate the differentiation and maturation of neurons in vitro and in vivo (Meier and Jorgensen, 1986; Meier et al., 1987; Spoerri, 1988; Belhage et al., 1990; Barbin et al., 1993; see Meier et al., 1991, for review). Immature neurons are depolarized by GABA (Fiszman ct al., 1990, 1993; Cherubini et al., 1991), resulting frequently in an influx of $\mathrm{Ca}^{2+}$ (Yuste and Katz, 1993). These observations suggest that $\mathrm{GABA}_{\mathrm{A}}$ receptors expressed pre- and perinatally mediate nonsynaptic actions of GABA in contrast to receptors expressed in the adult brain.

In view of the structural diversity of $\mathrm{GABA}_{\mathrm{A}}$ receptors (for review, see Mohler et al., 1990; Olsen and Tobin, 1990; Seeburg et al., 1990; Duble and Martin, 1992), changes in receptor function during ontogeny are likely to be based on alterations of their molecular structure. In particular, the variations in preponderance of benzodiazepine type I (BZ I) and type II (BZ II) binding sites during ontogeny (Candy and Martin, 1979; Lippa et al., 1981; Chisholm et al., 1983) point to alterations in the expression of $\alpha$-subunits. BZ I binding sites correspond to receptors containing the $\alpha \mathrm{l}$-subunit, whereas BZ II sites are a heterogeneous population arising from receptors containing the $\alpha 2-, \alpha 3-$, or $\alpha 5$-subunit (Pritchett et al., 1989a; Pritchett and Seeburg, 1990; McKernan et al., 1991b; Zezula and Sieghart, 1991; Doble and Martin, 1992; Mohler et al., 1992; Marksitzer et al., 1993). The subunits $\alpha 1$ and $\alpha 2$, being representative for 
the BZ I and BZ II binding sites, were therefore chosen to monitor a potential switch in $\mathrm{GABA}_{\mathrm{A}}$-receptor expression during ontogeny.

Since synaptogencsis, and notably the formation of inhibitory synapses, takes place mostly postnatally in rat brain (Blue and Parnavelas, 1983a; Miller, 1986; Kageyama and Robertson, 1993), $\mathrm{GABA}_{\mathrm{A}}$-receptor expression was analyzed immunohistochemically between birth ( $\mathrm{P} 0$ ) and adulthood. The distribution of the $\alpha 1$ - and $\alpha 2$-subunits was compared to that of the $\beta 2,3$-subunits, which are widely distributed in both neonatal and adult brain (Schoch et al., 1985; Richards et al., 1987; Benke et al., 199 lb; Cobas et al., 1991). This study was expected to provide evidence for changes in $\mathrm{GABA}_{\mathrm{A}}$-receptor subunit composition of individual neurons during ontogeny.

\section{Materials and Methods}

Subunit-specific antisera raised against synthetic peptides derived from the $\alpha 1$ - and $\alpha 2$-subunit cDNA sequences ( $\alpha 1$-subunit residues 1-16; $\alpha 2$ subunit residues 1-9) (see Benke et al., 1991a,b; Gao et al., 1993; Marksitzer et al., 1993, for characterization) and the monoclonal antibody bd-17 (Schoch et al., 1985), recognizing both the $\beta 2$ - and $\beta 3$-subunits (Ewert et al., 1990), were used as primary antibodies. The $\alpha 2$-subunit antibody was purified on a peptide affinity matrix, as described in Benke et al. (1991b).

Tissue preparation. Sprague-Dawley rats aged $0,1,2,4,6,10,14$, 20 , and $28 \mathrm{~d}$ and adults $(>60 \mathrm{~d})$ were anesthetized with chloral hydrate and perfused through the ascending aorta with ice-cold phosphate-buffered saline (PBS) followed by a solution of $0.15 \mathrm{M}$ phosphate buffer (pH 7.4) containing 4\% paraformaldehyde and $15 \%$ of a saturated solution of picric acid (Somogyi and Takagi, 1982). Brains were removed immediately after the perfusion, postfixed for $2 \mathrm{hr}$ (adults) and $24 \mathrm{hr}$ (juveniles) and stored at $4^{\circ} \mathrm{C}$ in $10 \%$ dimethylsulfoxide in PBS for cryoprotection. Parasagittal sections were cut from frozen blocks with a sliding microtome and collected in PBS. The thickness of the sections varied between $40 \mu \mathrm{m}$ for adult tissue and $70 \mu \mathrm{m}$ for neonatal tissue.

Immunohistochemistry. For immunoperoxidase staining, sections were incubated free-floating for $18 \mathrm{hr}$ at $4^{\circ} \mathrm{C}$ with primary antibodies diluted in PBS with $2 \%$ normal rat serum, $2 \%$ normal goat serum and $0.2 \%$ Triton X-100. The following dilutions were used: $\alpha 1$-subunit antiserum, 1:20,000; affinity-purified $\alpha 2$-subunit antiserum, $0.3 \mu \mathrm{g} / \mathrm{ml} ;$ bd-17, $1: 10,000$. For sections from neonatal brains, the incubation in primary antibodies was limited to $3 \mathrm{hr}$ at room temperature. Sections were then processed for the avidin-biotin method of Hsu et al. (1981), using Vectastain Elite kits (Vector Laboratories) and diaminobenzidine hydrochloride as chromogen. Secondary antibodies were also diluted in PBS containing $2 \%$ rat serum and $2 \%$ goat serum to prevent nonspecific binding, in particular in sections from neonatal rats. Following the staining procedure, sections were mounted onto gelatin-coated slides, air dried, dehydrated and coverslipped out of xylene. The distribution of the $\alpha 1-, \alpha 2$-, and $\beta 2,3$-subunit immunoreactivity (-IR) was analyzed in bright field microscopy and photographed with Kodak Tmax 100 films. Adjacent sections were Nissl-stained with cresyl violet for cytoarchitectonic reference.
For double immunofluorescence staining, sections were incubated in a mixture of two primary antibodies diluted in PBS $(\alpha 1$-subunit antiserum, 1:3000; affinity-purified $\alpha 2$-subunit antibody, $0.5 \mu \mathrm{g} / \mathrm{ml}$; bd-17, $1: 2000$ ) with $2 \%$ normal rat serum and $0.2 \%$ Triton $X-100$. Sections were then washed with PBS and incubated for $1 \mathrm{hr}$ at room temperature with a mixture of secondary antibodies (Jackson Immunoresearch) coupled to DTAF (1:100) and to Cy3 (1:200), diluted in PBS with $2 \%$ normal rat serum and $2 \%$ normal goat serum. Sections were mounted onto gelatin-coated slides, air dried and coverslipped with buffered glycerol. Colocalization of subunits $(\alpha 1 / \alpha 2, \alpha 1 / \beta 2,3, \alpha 2 / \beta 2,3)$ was analyzed by confocal laser microscopy (Bio-Rad, MRC600), using a dual channel illumination for simultaneous recording of the images corresponding to each fluorochrome.

The addition of rat serum to the incubation buffers resulted in a significant reduction of background staining as compared to other blocking sera. Controls for specificity were performed by replacing the primary antibodies with nonimmune serum, or by preincubating the $\alpha 1-$ and $\alpha 2$-subunit antisera with increasing concentrations of their respective peptide-antigen $(1-10 \mu \mathrm{g} / \mathrm{ml})$. In addition, the absence of cross-reactivity between the secondary antibodies in the double-staining experiments was verified by omitting one of the primary antibodies during the overnight incubation.

\section{Results}

Differential postnatal maturation of the $\alpha 1-, \alpha 2-$, and $\beta 2,3-$ subunit immunoreactivities in neonatal brain

Changes in the distribution of the $\mathrm{GABA}_{\mathrm{A}}$-receptor $\alpha 1-, \alpha 2-$, and $\beta 2,3$-subunits were analyzed between birth $(\mathrm{P} 0)$ and adulthood in sections processed for immunoperoxidase staining. Each of these subunits exhibited a different maturation pattern, as evidenced by age-dependent changes in their distribution throughout the brain (Figs. 1-3). The $\alpha 1$-subunit immunoreactivity (-IR) was low at birth in major brain areas, such as neocortex, hippocampus, thalamus, and cerebellum. It increased gradually thereafter with striking regional differences in the onset of expression, reflected by sharp boundaries between stained and unstained areas (Fig. 1). Such boundaries were particularly prominent in neonatal animals between the subiculum and hippocampus and between the pretectal area and the thalamus (Fig. 1). Even more striking was the area-specific maturation of the $\alpha 1$-subunit-IR in neocortex, with staining of primary somatosensory and visual cortex preceding by several days that in association areas (Fig. 1). At 3 weeks of age, the $\alpha 1$-subunit-IR revealed a widespread and prominent expression of this subunit in most brain areas (Fig. 1). An essentially opposite maturation pattern was found for the $\alpha 2$-subunit-IR, being widespread and intense at birth, but restricted to some forebrain areas at P20, including neocortex, hippocampus, striatum and olfactory bulb (Fig. 2). This reduction resulted from a gradual disappearance of the $\alpha 2$-subunit-IR during the first two postnatal weeks, as

\footnotetext{
Figure 1. Region-specific increase in $\alpha 1$-subunit-IR during postnatal development, as visualized in parasagittal sections processed for immunoperoxidase staining. At birth $(P O)$, most of forebrain was devoid of staining, in contrast to the brainstem and mesencephalon, which appeared moderately to intensely stained. In cerebral cortex, a faint $\alpha 1$-subunit-IR delineated the presumptive boundarics of primary sensory $(S I)$ and visual cortex (VI) (arrowheads). At P4, a substantial increase in $\alpha 1$-subunit-IR staining was evident throughout the brain, except in thalamus and striatum, which remained largely devoid of staining. In cerebral cortex, intense staining was mostly restricted to layers III-IV of primary sensory areas arrowheads). In cerebellum, the $\alpha 1$-subunit-IR was confined to the Purkinje cell layer at this age (arrow). At P20, a widespread and intense $\alpha 1$ subunit-IR decorated most brain areas, forming a pattern similar to that seen in the adult. Note in particular the prominent staining of thalamus and cerebellum, and the decrease in $\alpha 1$-subunit-IR in the spinal trigeminal nucleus (open arrow), as compared to P4. Scale bars, $1 \mathrm{~mm}$.

Figure 2. Region-specific decrease in $\alpha 2$-subunit-IR during postnatal development, as visualized in parasagittal sections processed for immunoperoxidase staining. At birth $(P O)$, an intense and widespread staining was seen throughout most of the brain, except in the deep cortical layers and reticular nucleus of the thalamus. At $P 4$, a decrease in $\alpha 2$-subunit-IR was evident, notably in the subthalamic area, mesencephalon, and pons. By contrast, the thalamus and pallidum remained intensely stained. At $P 20$, a further reduction was observed and the $\alpha 2$-subunit-IR was mostly confined to telencephalic areas, including olfactory bulb, striatum, cerebral cortex, and hippocampus. In addition, staining for the $\alpha 2$-subunit was apparent in brainstem motor nuclei, spinal trigeminal nucleus, and molecular layer of the cerebellum. Arrowheads in each panel point to regions (reticular nucleus of the thalamus and superior olivary complex) that remain devoid of $\alpha 2$-subunit during development. Scale bars, 1 mm.
} 

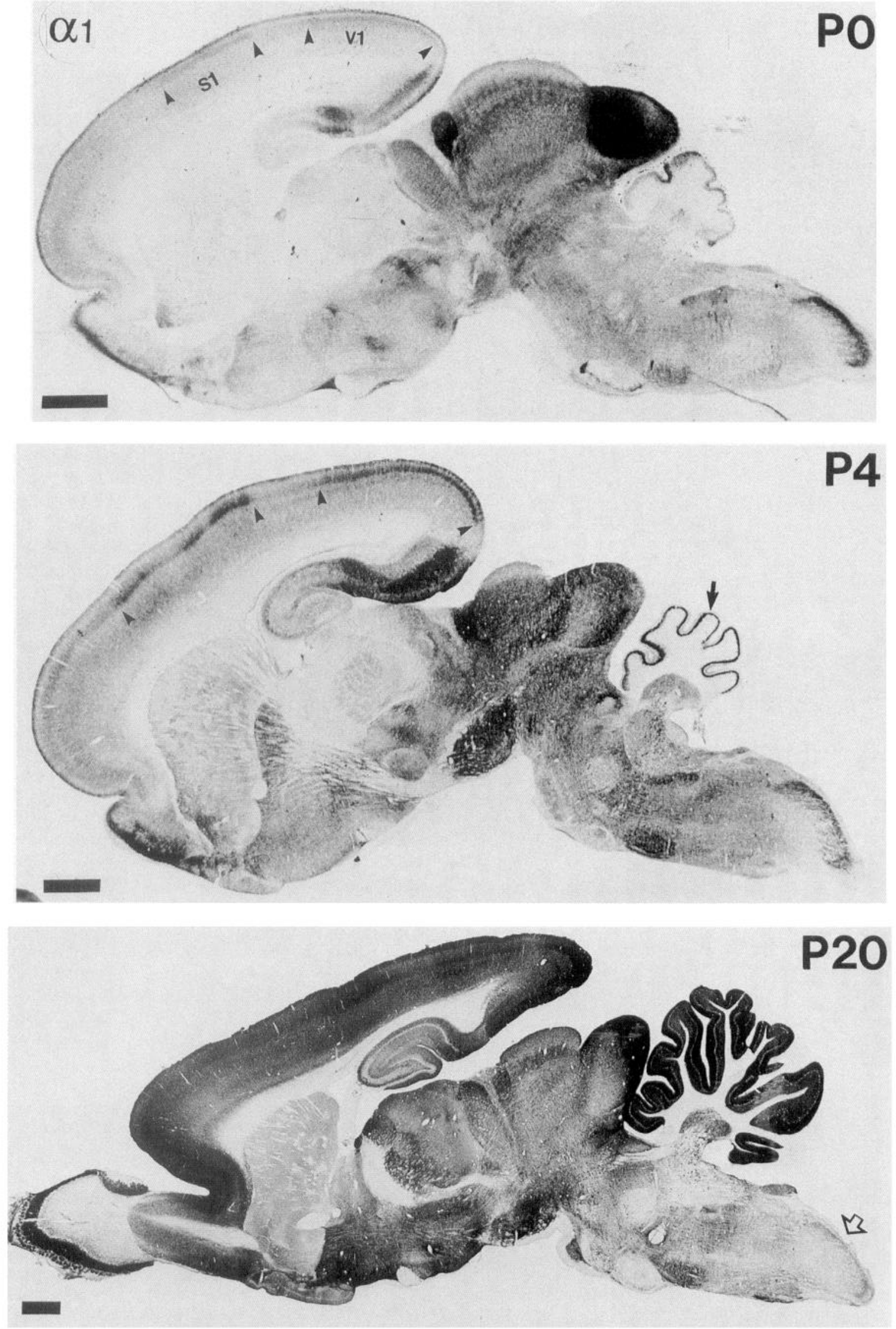

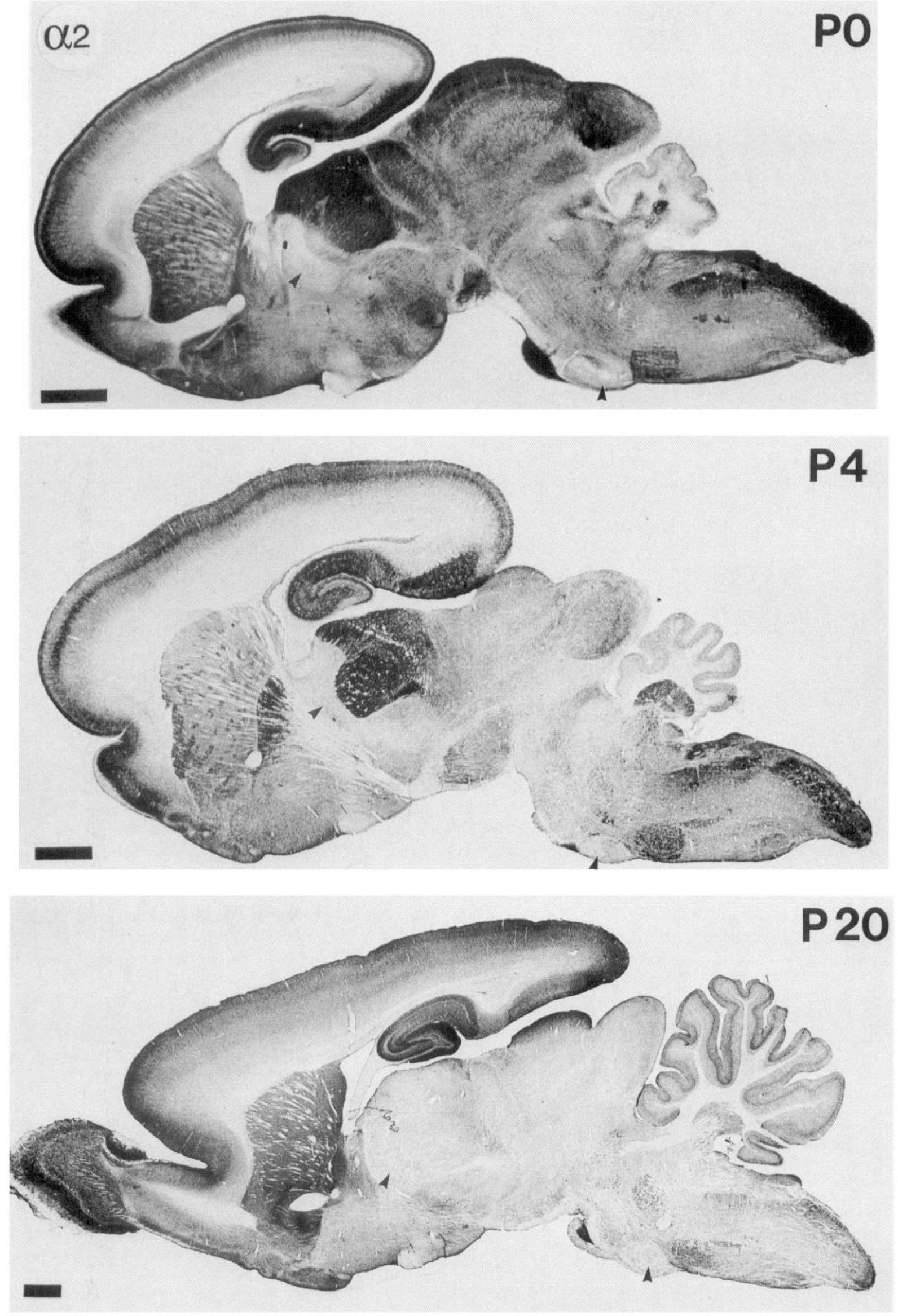
seen in pallidum, thalamus, substantia nigra, tectum, deep cerebellar nuclei, and brainstem reticular formation. Nevertheless, the $\alpha 2$-subunit-IR increased during development in certain forebrain areas, reaching high levels of expression in the adult (Fig. 2 ). In contrast, the $\beta 2,3$-subunits, covisualized with the monoclonal antibody bd-17, displayed a ubiquitous distribution in both neonatal and adult brain, roughly equivalent to the global distribution of the $\alpha 1$ - and $\alpha 2$-subunits (Fig. 3). Only a few changes in the distribution of the $\beta 2,3$-subunit-IR were observed during postnatal ontogeny, pointing to a widespread expression of these subunits at every developmental stage. Still, an increase in $\beta 2,3$-subunit staining was observed in striatum, pallidum, substantia nigra, cerebellum and brainstem reticular formation (Fig. 3). Conversely, the $\beta 2,3$-subunit staining gradually disappeared in specific nuclei after the first postnatal week, particularly in the reticular nucleus of the thalamus and in the superior and the inferior olivary complexes (Fig. 3). The distinct maturation patterns of the subunits examined here point to structural modifications of major $\mathrm{GABA}_{\mathrm{A}}$-receptor subtypes during postnatal development.

The specificity of the immunohistochemical staining was based on the extensive biochemical and immunohistochemical characterization of the respective antibodies (Schoch et al., 1985; Richards et al., 1987; Benke et al., 1991a,b; Gao et al., 1993; Marksitzer et al., 1993). In addition, the reaction of the $\alpha 1$ - and $\alpha 2$-subunit antibodies was abolished in both neonatal and adult brain sections following preincubation of the antisera with their respective peptide antigens $(1-10 \mu \mathrm{g} / \mathrm{ml})$ or replacement with nonimmune serum (not shown).

\section{Switch in $\alpha 1$ - and $\alpha 2$-subunit immunoreactivity}

At birth, the $\alpha 1$-subunit-IR was mostly restricted to brainstem, notably at mesencephalic levels, basal forebrain, and olfactory areas. In these regions, numerous strongly immunopositive neuronal cell bodies and dendrites could be observed, as well as a diffuse staining of the neuropil, which predominated in the tectum and olfactory cortex. In addition, a faint $\alpha 1$-subunit-IR was observed in cerebellum (Purkinje cell layer), and in the presumptive primary somatosensory and visual areas of cerebral cortex (Fig. 1). During the first postnatal week, the $\alpha 1$-subunitIR gradually became apparent in most brain regions. The main exceptions were the thalamus, which became stained only after P6, and the striatum and olfactory bulb granule cell layer, which appeared unstained at every age examined. The staining intensity increased rapidly after P6, resulting in the formation of the adult pattern by P20 (Fig. 1). In contrast to this increase in $\alpha 1$ subunit expression, the $\alpha 2$-subunit-IR was strong at $\mathrm{P} 0$ throughout the brain, in particular in those regions devoid of $\alpha 1$-subunit staining (Fig. 2). During postnatal devclopment the $\alpha 2$-subunit staining decreased in many areas (Fig. 2), first in the mesencephalon and hypothalamus, and during the second and third postnatal weeks in thalamus, pallidum, and medulla. In the adult, these brain regions were largely devoid of $\alpha 2$-subunit-IR, whereas staining remained intense in regions exhibiting little $\alpha 1$-subunit-IR.

The developmental switch in the expression of the $\alpha 1$ - and $\alpha 2$-subunit-IR was particularly evident in thalamus (Fig. 4), and pallidum (Fig. 5), where the $\alpha 2$-subunit-IR was initially very prominent and was gradually replaced by the $\alpha 1$-subunit-IR. Thus, in most brain areas, the $\alpha 2$-subunit-IR was expressed only transiently during development, being replaced by the $\alpha 1$-subunit-IR. In the few regions that are devoid of $\alpha 1$-subunit-IR, the $\alpha 2$-subunit was either never expressed (e.g., reticular nucleus of the thalamus or superior olivary complex; see Fig. 2), or it was intense at cvery agc cxamined (c.g., striatum, olfactory bulb granule cell layer).

On the cellular level, individual neurons could be easily distinguished by their staining on the soma and dendrites, notably in olfactory bulb, basal forebrain, pallidum, and brainstem. In thalamus, striatum, and cerebral cortex, the staining appeared diffuse, being more intense in the neuropil than in cell bodies. The disappearance of the $\alpha 2$-subunit-IR during development affected all immunoreactive neurons in a given region and was not due to a loss of staining in a subset of cells (see Figs. 4, 5). In regions where individual neurons could be well distinguished, the loss of immunoreactivity was first confined to dendrites and in a second phase staining disappeared from cell bodies. Conversely, the increase in $\alpha 1$-subunit-IR corresponded to the appearance of staining, first faint and gradually more intense, on most cells present in a given nucleus (Figs. 4,5 ).

In general, the increase in $\alpha 1$-subunit-IR preceded by several days the decrease in $\alpha 2$-subunit staining, resulting in the coexpression of both subunits during a limited time window. In the mesencephalon, coexpression of the $\alpha 1$ - and $\alpha 2$-subunitIR was seen between birth and P4 (Figs. 1, 2); in the pallidum, coexpression extended from P1 to P10 (Figs. 1, 2, 5) and in thalamus (ventrobasal complex) from P6 to P14 (Figs. 1, 2, 4). To determine whether this transient coexpression on the regional level corresponded to the coexistence of subunits within individual neurons, sections processed for double-immunoflu-

\footnotetext{
Figure 3. Stable expression of the $\beta 2,3$-subunit-IR during postnatal development, as visualized in parasagittal sections processed for immunoperoxidase staining. Most brain regions were moderately to intensely stained at every age. An increase in staining intensity was evident in striatum, resulting in the disappearance of the patchy staining seen at $P 0$ and $P 4$, and in pallidum. In addition, the $\beta 2,3$-subunit-IR increased dramatically in cerebellum, forming at each age a pattern very similar to that seen for the $\alpha 1$-subunit-IR (Fig. 1). Also note the transient $\beta 2,3-$ subunit-IR in the superior olivary complex (long arrows) and reticular nucleus of the thalamus (short arrows). In both nuclei, the prominent staining seen during early development had disappeared by $P 20$. Scale bars, $1 \mathrm{~mm}$.

Figure 4. Developmental switch in the expression of the $\alpha 1$ - and $\alpha 2$-subunit-IR in thalamus between birth $(P 0)$ and $P 20$, as visualized in parasagittal sections processed for immunoperoxidase staining. The massive increase in $\alpha 1$-subunit-IR observed between $P 10$ and $P 20$ was paralleled by a nearly complete loss of $\alpha 2$-subunit-IR. At $P 10$, staining for the $\alpha 1$-subunit was weak and confined to the ventrobasal complex (VB); a rapid increase leading to the adult pattern occurred during the third postnatal week. Similarly, the decrease in $\alpha 2$-subunit-IR took place mostly between $P I 0$ and $P 20$. Note that the reticular nucleus $(R t)$ was unstained with both antisera at every age examined. $L D$, laterodorsal nucleus. Scale bars, $200 \mu \mathrm{m}$. Figure 5. Comparative developmental maturation of the $\alpha 1$ - and $\alpha 2$-subunit-IR in the striatum $(C P u)$ and globus pallidus (GP), as visualized in parasagittal sections processed for immunoperoxidase staining. The striatum remained largely devoid of $\alpha 1$-subunit-IR at every age examined, whereas the $\alpha 2$-subunit-IR increased gradually to reach adult levels by P20. In the globus pallidus, the $\alpha 1$ - and $\alpha 2$-subunit-IR exhibited opposite maturation patterns, leading to a switch in subunit expression similar to that seen in the thalamus (Fig. 4). Whereas only one of the subunits was present at birth $(\alpha 2)$ and at $P 2 O(\alpha 1)$, both subunits were observed around $P 6$, exhibiting very similar staining patterns. Scale bar, $50 \mu$ m.
} 

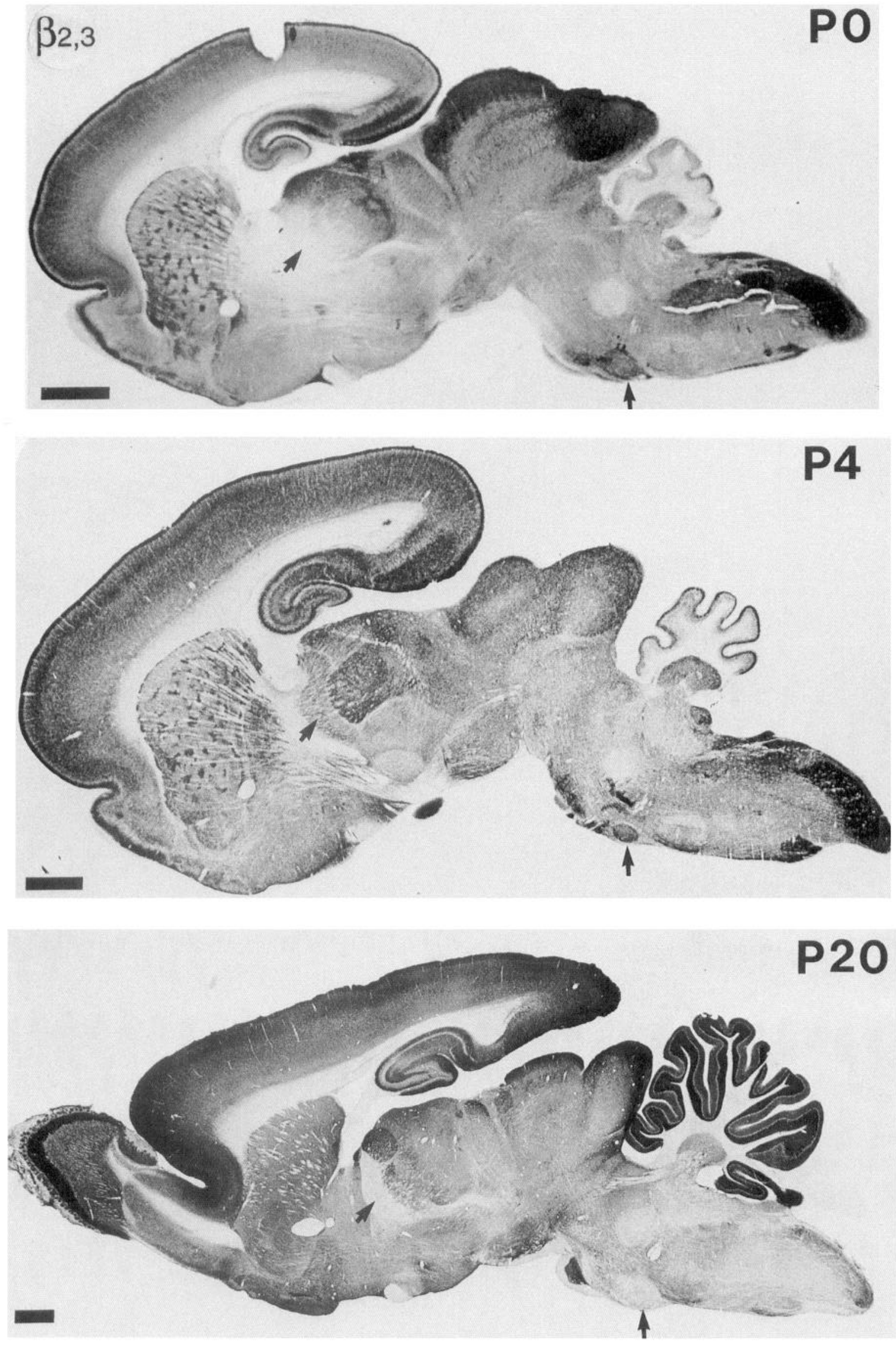

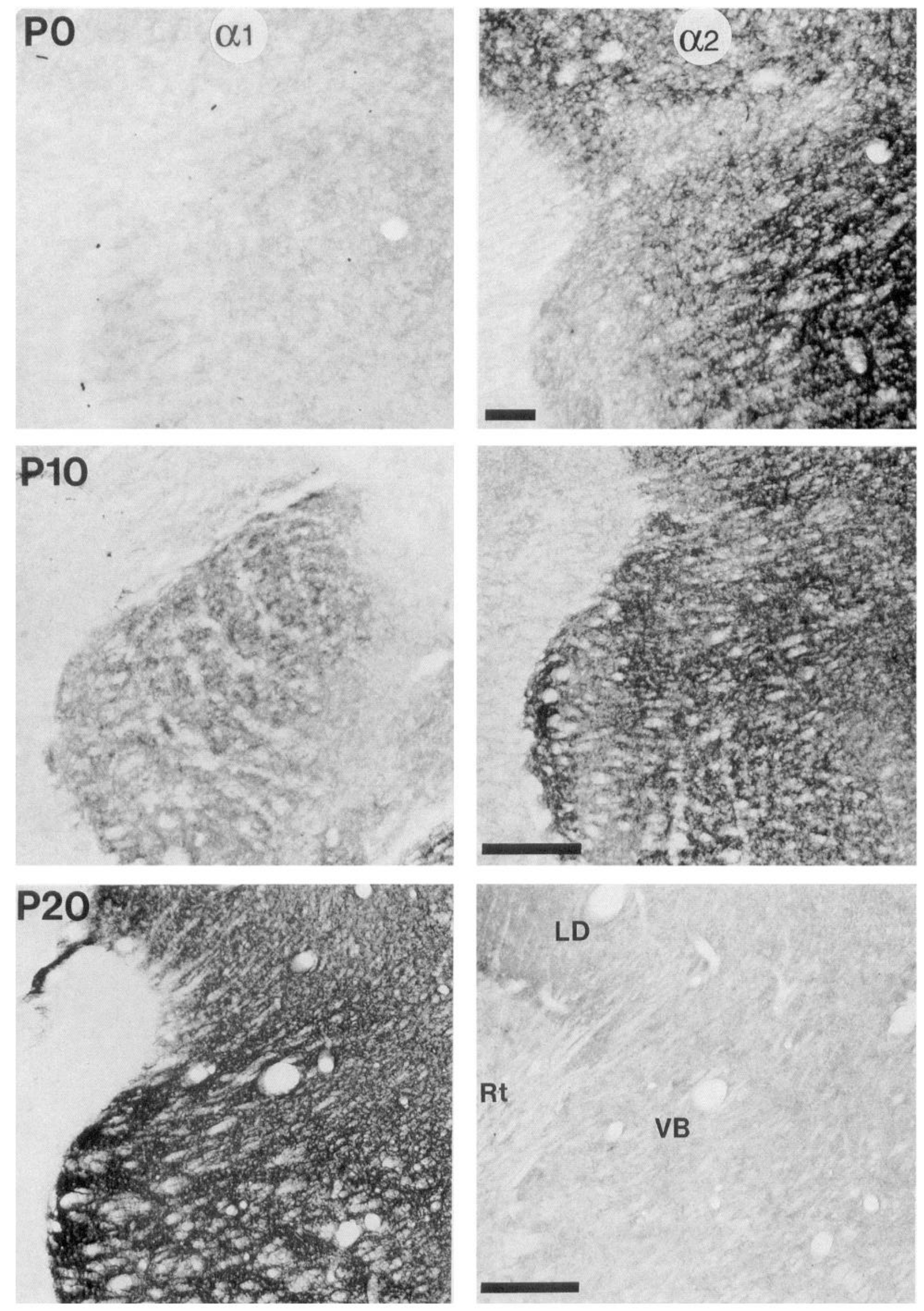

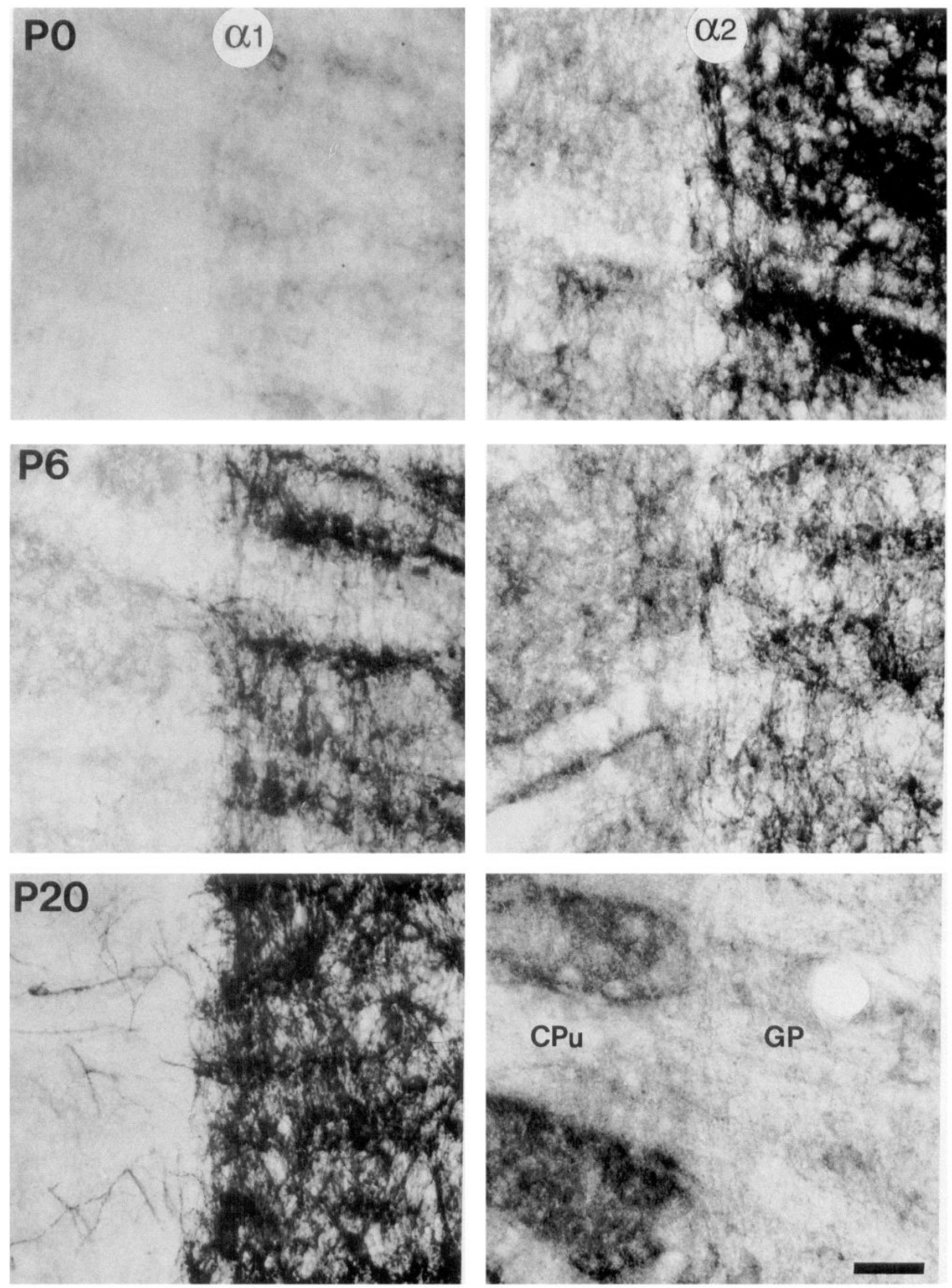

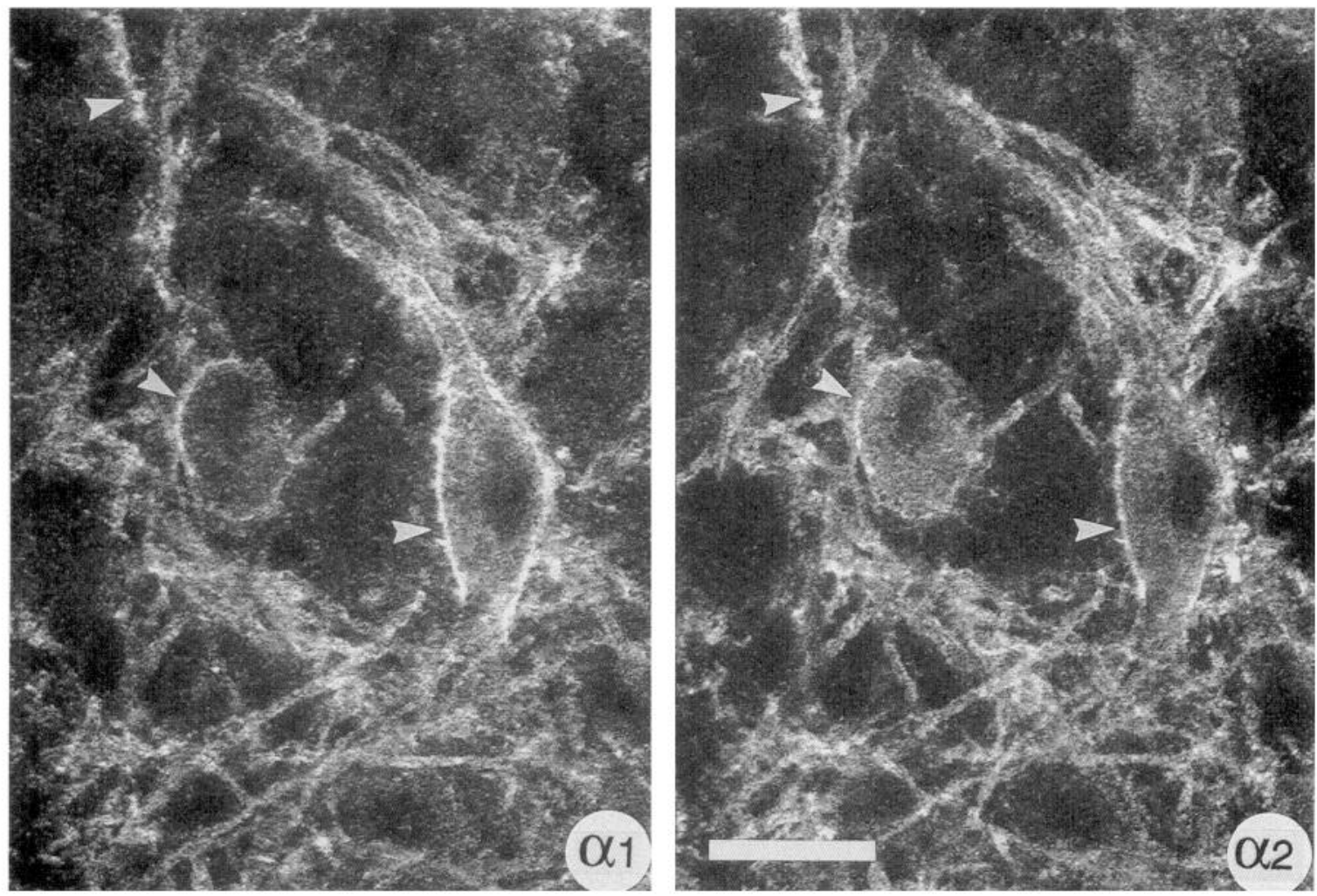

Figure 6. Colocalization of the $\alpha 1$ - and $\alpha 2$-subunit-IR within individual neurons in the globus pallidus, as visualized by confocal laser microscopy in a section processed for double-immunofluorescence staining. In these video images, intense staining appears white. Note that both subunits exhibit very similar distributions in the plasma membrane of positive cells (arrowheads). Scale bar, $20 \mu \mathrm{m}$.

orescence staining with the $\alpha 1$ - and $\alpha 2$-subunit antisera were analyzed by confocal laser microscopy. This analysis revealed an extensive colocalization of the $\alpha 1$ - and $\alpha 2$-subunit-IR within most neurons of the globus pallidus (Fig. 6), ventral pallidum, thalamus, tectum, brainstem reticular formation, and deep cerebellar nuclei. Moreover, on the subcellular level, both subunits exhibited nearly identical staining patterns, suggesting that they were colocalized in the plasma membrane (Fig. 6). Since only the $\alpha 1$-subunit-IR could be still detected at later stages, our observations suggest a switch between receptors containing the $\alpha 2$ - and $\alpha 1$-subunit in these neurons.

\section{Colocalization of the $\alpha 2$ - and $\beta 2,3$-subunits}

The major characteristic of the $\beta 2,3$-subunits-IR was its widespread occurrence throughout the brain at every age examined (Fig. 3). During the first postnatal week, the distribution of the $\beta 2,3$-subunit-IR was very similar to that of the $\alpha 2$-subunit, with most brain regions exhibiting an intense staining for both types of subunits (Figs. 2, 3), whereas at later stages, following the decrease in $\alpha 2$-subunit staining, co-expression was restricted to specific regions, which include the olfactory bulb, striatum, hippocampus, superficial layers of cortex and of superior colliculus. In the latter areas, the maturation of the $\alpha 2$ - and $\beta 2,3$-subunits was strikingly similar, suggesting that it may be coordinated within individual neurons. For instance, in the striatum, the $\alpha 2$ - and $\beta 2,3$-subunit-IR transiently formed a mosaic of intensely immunoreactive patches surrounded by weakly stained areas (Figs. 1, 2, 7). The patches were stained for each of these subunits, most prominently between $\mathrm{P} 0$ and $\mathrm{P} 6$ and disappeared gradually thereafter, as the staining became uniform throughout the striatum (Figs. 2, 3). Furthermore, high-resolution confocal laser microscopy revealed that the patches contained numerous intensely immunoreactive neurons and dendrites (Fig. 7) and were surrounded by weakly stained cells. These observations suggest a differential maturation of $\mathrm{GABA}_{\mathrm{A}}$ receptors in distinct compartments of the striatum, which may correspond to the patch and matrix architecture of the adult nucleus (Gerfen et al., 1987).

On the cellular level, colocalization of the $\alpha 2$ - and $\beta 2,3$-subunits was analyzed by double-immunofluorescence staining in two different situations (Fig. 8): (1) in regions where the $\alpha 2$ subunit is expressed only transiently and (2) in regions where the $\alpha 2$-subunit is expressed throughout development. In the first case, an extensive coexistence of the $\alpha 2$ - and $\beta 2,3$-subunits was observed within most neurons of the globus pallidus, thalamus, tectum, and deep cerebellar nuclei, before the onset of $\alpha 1$-subunit staining. As illustrated for the thalamus of a P6 rat (Fig. $8 A$ ), the coexistence of the $\alpha 2$ - and $\beta 2,3$-subunits was evident in the soma and dendrites of most neurons, suggesting coassembly in the plasma membrane. At later stages, the $\alpha 2$-subunitIR disappeared and the $\beta 2,3$-subunits became colocalized with the $\alpha 1$-subunit (see following section). In the second case, colocalization of the $\alpha 2$ - and $\beta 2,3$-subunits was observed at every developmental stage in olfactory bulb granule cells, dentate gyrus granule cells and hippocampal pyramidal cells (Fig. $8 B$ ). These findings suggest that the subunit combination $\alpha 2 / \beta 2,3$ may be commonly expressed in immature brain, whereas in the adult brain it may be restricted to specific neuronal populations.

In the adult brain, only a few regions were devoid of staining for bd-17, which include the reticular nucleus of the thalamus, 

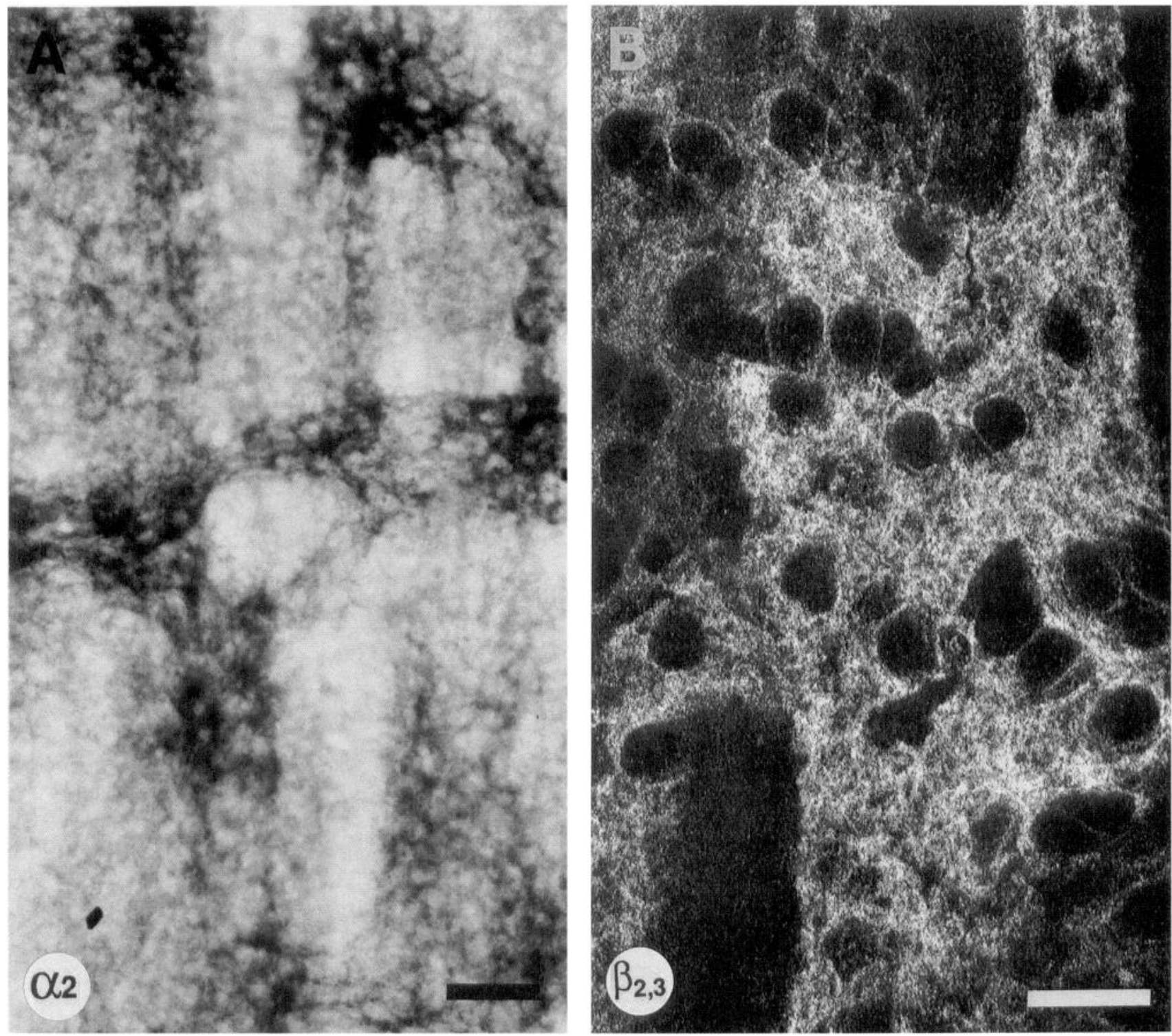

Figure 7. Patchy distribution of the $\alpha 2$ - and $\beta 2,3$-subunit-IR in the striatum of juvenile rats. $A$, Immunoperoxidase staining for the $\alpha 2$-subunit in a P0 rat, showing the distribution of patches surrounded by weakly stained areas. $B$, Immunofluorescence staining for the $\beta 2,3$-subunits, visualized by confocal laser microscopy (P4 rat). In this high-resolution video image, numerous strongly stained (white) neurons and dendrites are seen forming a patch of intense immunoreactivity. Scale bars: $A, 50 \mu \mathrm{m} ; B, 25 \mu \mathrm{m}$.

the superior olivary complex and the inferior olivary complex (Fig. 3). Interestingly, these regions were transiently stained during development (Figs. 3, 9). In the reticular nucleus of the thalamus, bd-17 staining became apparent between $\mathrm{P} 0$ and $\mathrm{P} 6$ and decreased thereafter to disappear in adult brain (Fig. 3). By contrast, in the inferior olivary complex, $\beta 2,3$-subunit staining was already very strong at $\mathrm{P} 0$, persisted as such during the first postnatal week and disappeared thereafter. After P20, the inferior olive appeared virtually devoid of immunoreactivity (Fig. 9). The $\beta 2,3$-subunit staining in the inferior olive during the first postnatal week was the most intense one throughout the brain at any age examined, pointing to a very prominent expression of these subunits at early developmental stages.

\section{Colocalization of the $\alpha 1$ - and $\beta 2,3$-subunits}

In the adult rat brain, the $\alpha 1$ - and $\beta 2,3$-subunits are extensively colocalized within individual neurons and are presumably coas- sembled in a majority of GABA $A_{A}$ receptors (Benke et al., 199lb; Fritschy et al., 1992). To determine when these subunits became colocalized during development, sections from various ages were processed for double-immunofluorescence staining and analyzed by confocal laser microscopy. These studies revealed an extensive coexistence of the $\alpha 1$ - and $\beta 2,3$-subunits in individual neurons of juvenile rat brain, in regions such as olfactory bulb (mitral cells), basal forebrain, cerebral cortex, tectum, brainstem, and cerebellum. On the subcellular level, colocalization of these subunits gave rise to nearly identical staining patterns, as illustrated in Figures 10 and 11.

In regions exhibiting a restricted $\alpha 1$-subunit-IR but a widespread $\beta 2,3$-subunit-IR, such as the hippocampus (Fig. 12), staining for the $\beta 2,3$-subunits was also observed in neuron populations lacking the $\alpha 1$-subunit. While a prominent signal was seen with bd-17 on the soma and dendrites of pyramidal cells and dentate gyrus granule cells, colocalization with the $\alpha 1$-sub- 

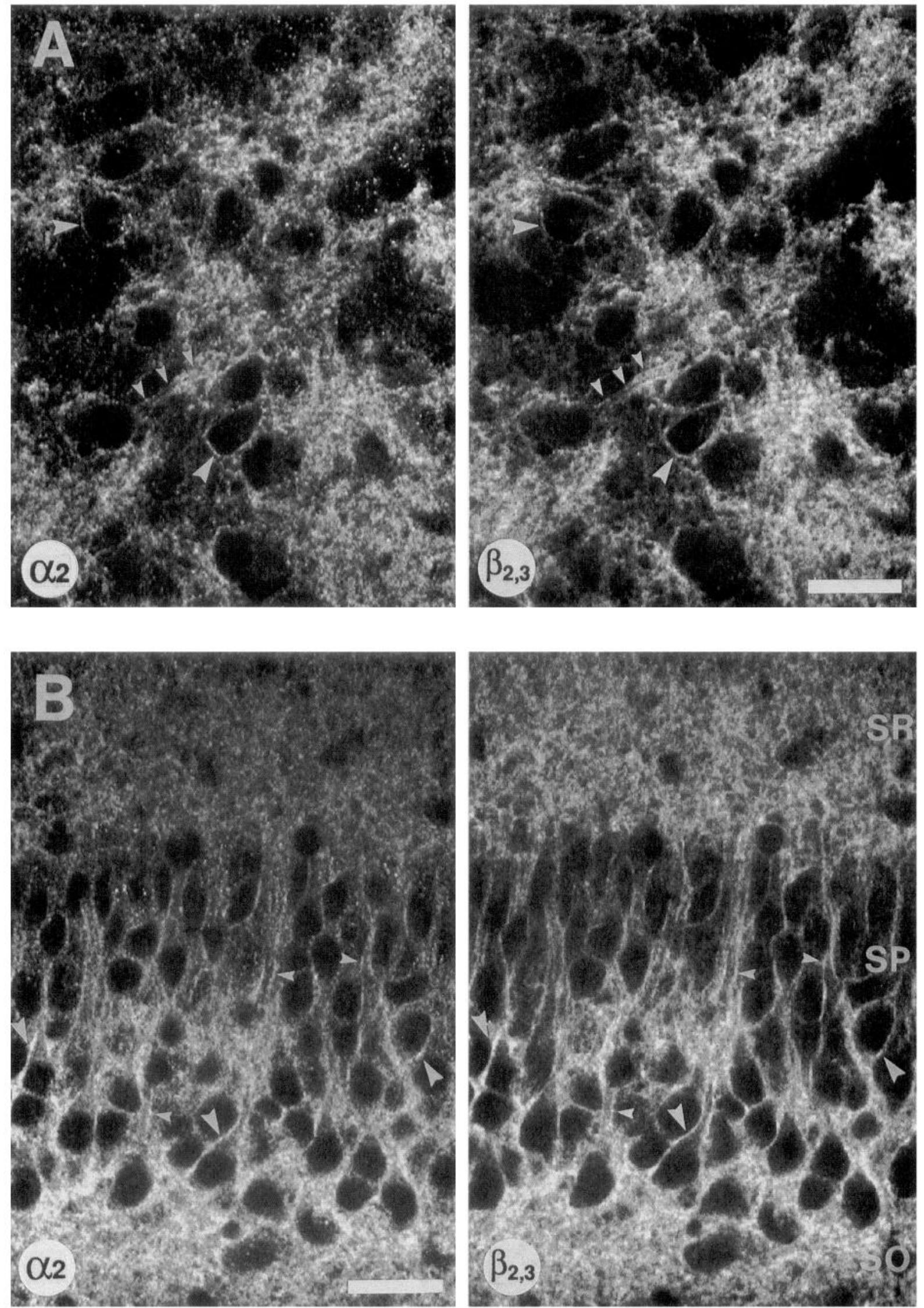

Figure 8. Colocalization of the $\alpha 2$ - and $\beta 2,3$-subunit-IR, as visualized by confocal laser microscopy in sections of a P6 rat processed for doubleimmunofluorescence staining. $A$, In the ventrobasal complex of thalamus, where the $\alpha 2$-subunit is only transiently expressed, numerous neurons (large arrowheads) and their proximal dendrites (small arrowheads) are double labeled at this age. In the neuropil, the distribution of either subunit was too diffuse to assess colocalization on distal dendrites. $B$, In the CA1 region of the hippocampus, colocalization of the $\alpha 2-$ and $\beta 2,3$-subunits is evident on the somata of pyramidal cells (large arrowheads) and on their apical dendrites (small arrowheads). In the stratum oriens (SO) and stratum radiatum $(S R)$ an intense and diffuse staining can be seen for each subunit. Scale bars, $25 \mu \mathrm{m}$. 

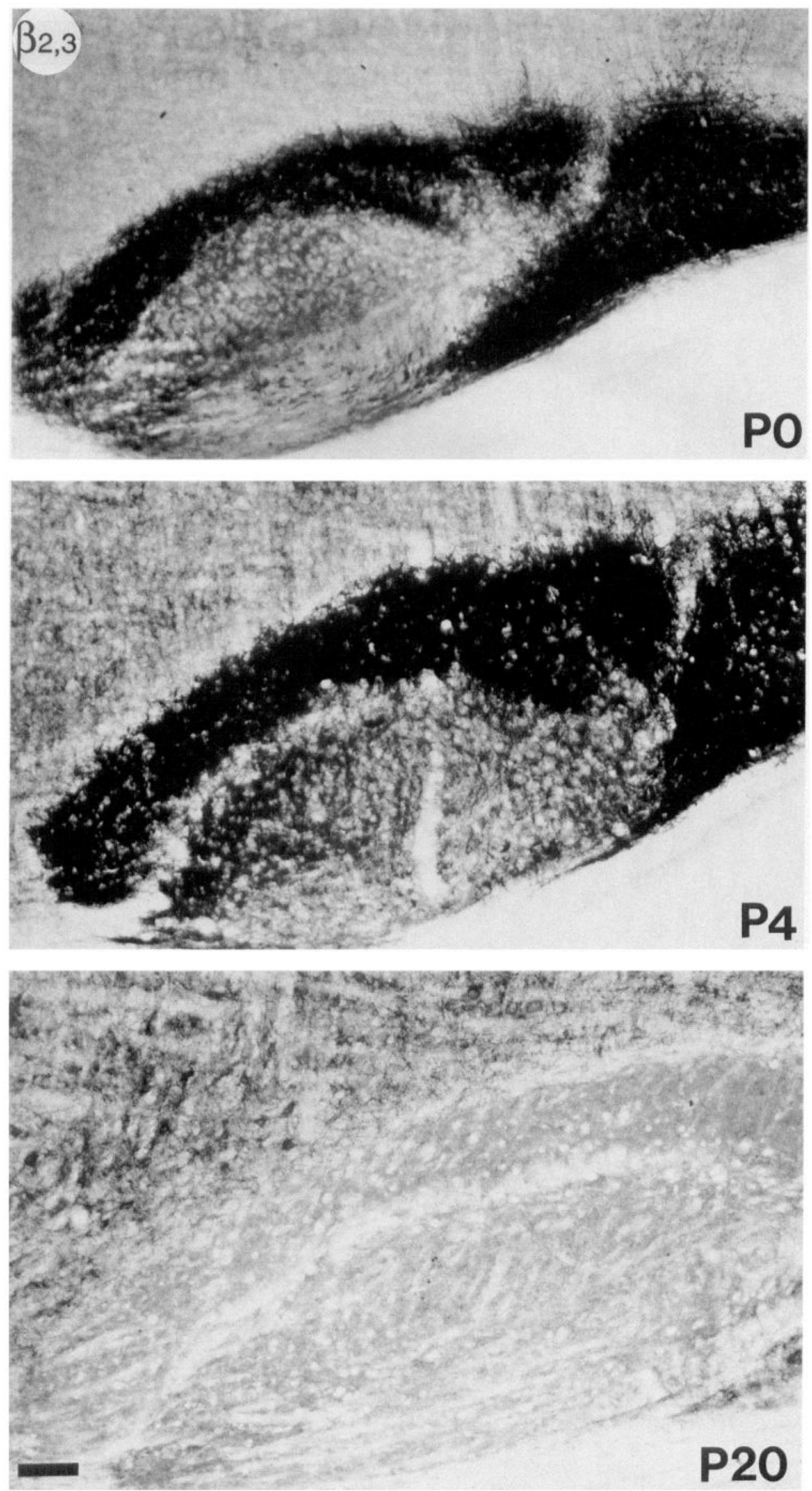

Figure 9. Transient expression of the $\beta 2,3$-subunits in the inferior olivary complex, as visualized in parasagittal sections processed for immunoperoxidase staining. A very intense immunoreaction was observed at $P 0$ and $P 4$, which decreased thereafter and became faint at $P 20$. Note the gradual increase in $\beta 2,3$-subunit-IR in the reticular formation, dorsal to the inferior olive. Scale bar, $100 \mu \mathrm{m}$. 

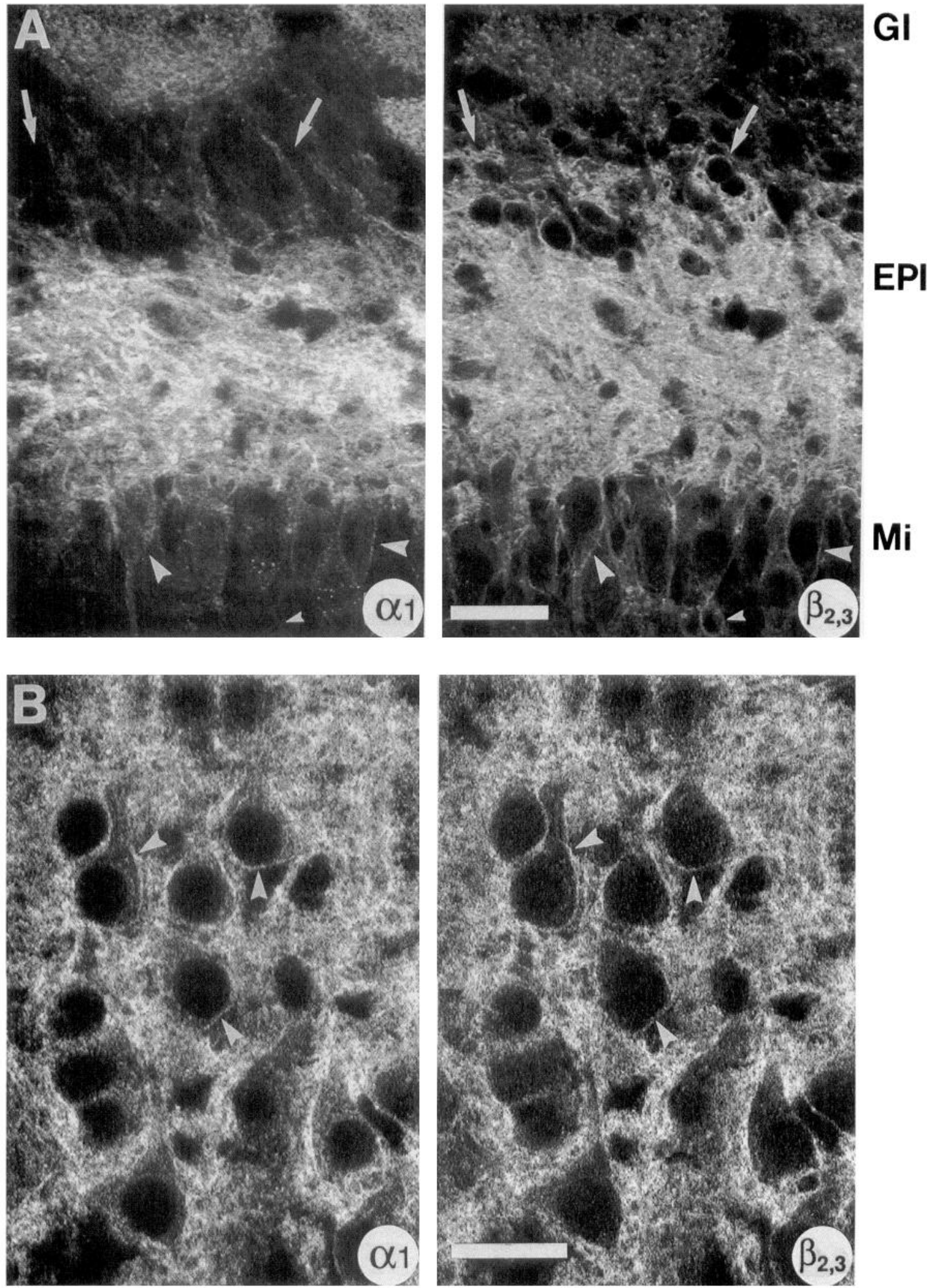

Figure 10. Colocalization of the $\alpha 1$ - and $\beta 2,3$-subunit-IR, as visualized by confocal laser microscopy in sections of P4 rats processed for doubleimmunofluorescence staining. $A$, In olfactory bulb, colocalization was evident in glomeruli $(G l)$, external plexiform layer $(E P l)$ and mitral cell layer (Mi) (large arrowheads); in addition, staining for the $\beta 2,3$-subunits only was observed in the periglomerular area (arrows) and in granule cells (small arrowheads). $B$, In cerebral cortex layer III, both subunits exhibited very similar staining patterns, notably on the soma of pyramidal cells (arrowheads). Scale bars: $A, 25 \mu \mathrm{m} ; B, 20 \mu \mathrm{m}$. 

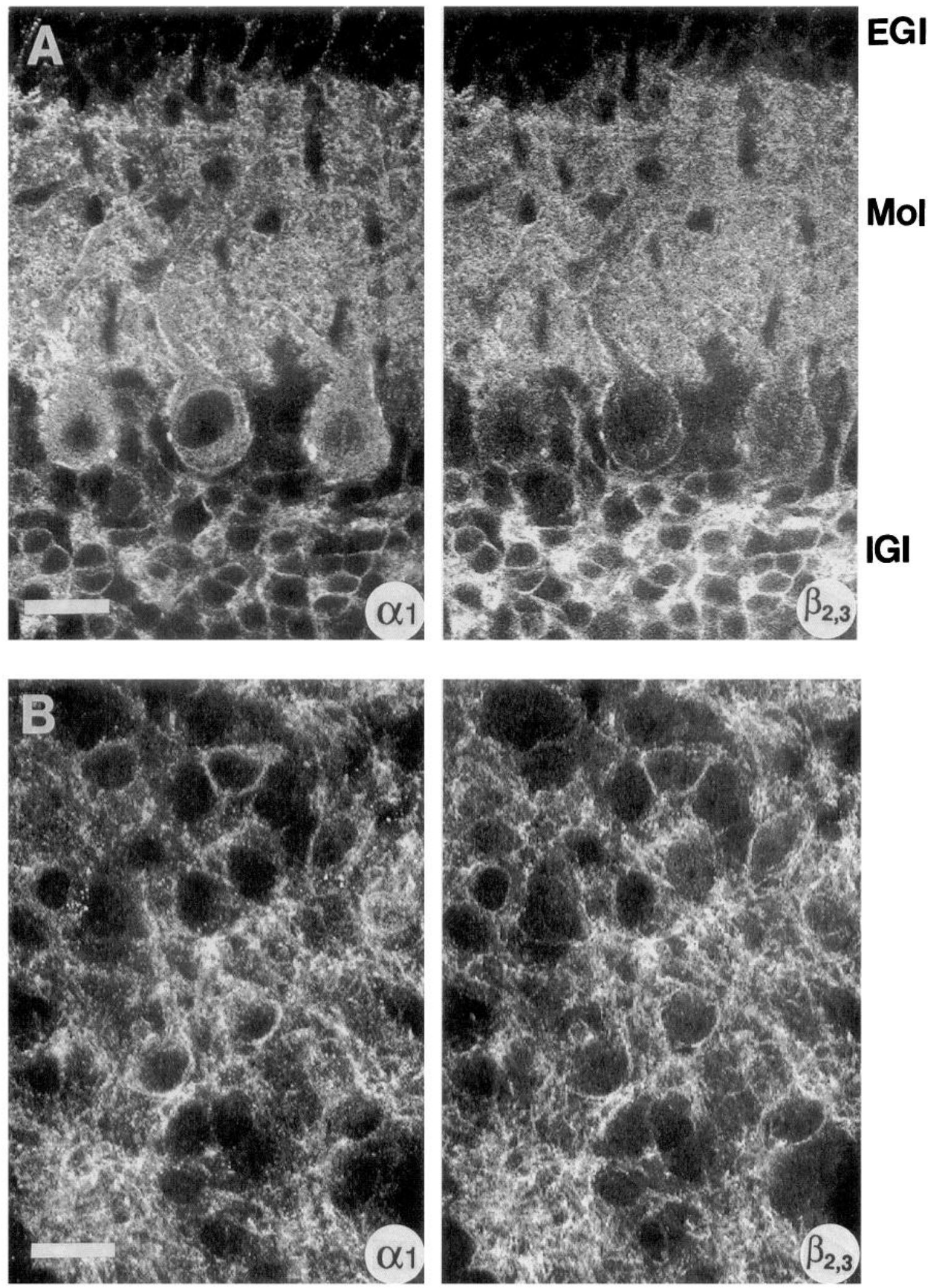

Figure 11. Colocalization of the $\alpha 1$ - and $\beta 2,3$-subunit-IR, as visualized by confocal laser microscopy in sections processed for double-immunofluorescence staining. $A$, In cerebellum (P10 rat), both markers decorated the soma and dendrites of Purkinje cells, revealing their morphology in considerable detail. Note their nearly identical distribution on the subcellular level. Colocalization was also seen in the internal granule cell layer $(I G l)$, although staining was more intense for the $\beta 2,3$-subunits than for the $\alpha 1$-subunit. The external germinal layer $(E G l)$ was devoid of immunoreactivity for either subunit. $\mathrm{Mol}$, molecular layer of the cerebellum. $B$, In spinal trigeminal nucleus, pars caudalis (P6 rat), nearly identical staining patterns were observed, pointing to an extensive colocalization of the $\alpha 1$ - and $\beta 2,3$-subunits. Scale bars, $25 \mu \mathrm{m}$. 

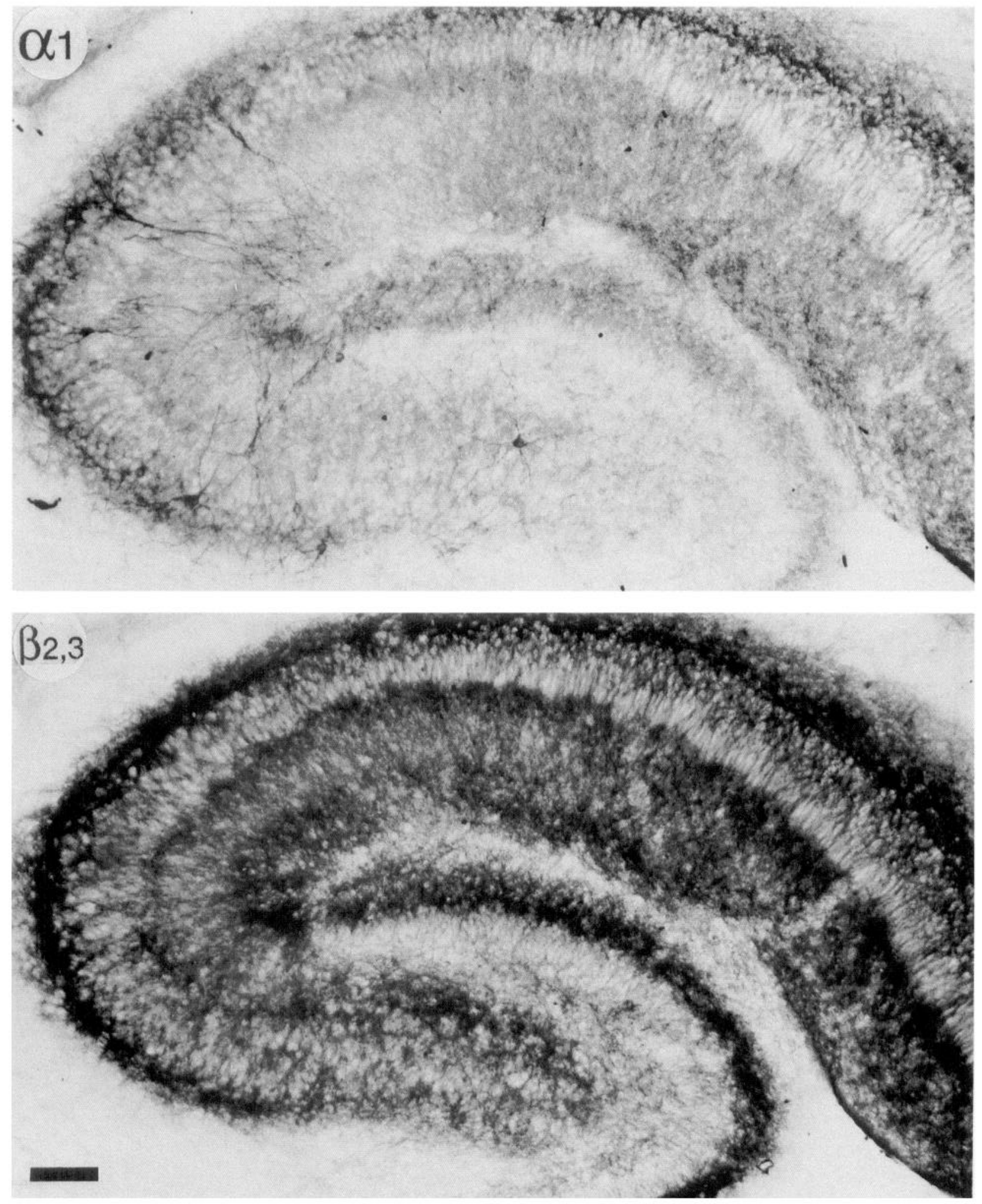

Figure 12. Differential distribution of the $\alpha 1$ - and $\beta 2,3$-subunits in the hippocampus, as visualized by immunoperoxidase staining in a P4 rat. Intense staining for the $\beta 2,3$-subunits was evident throughout the hippocampus, decorating the somatic and dendritic layers, particularly the stratum oriens of the CA1-CA3 areas and the molecular layer of the dentate gyrus. By contrast, the $\alpha 1$-subunit-IR was most prominent in isolated interneurons in the CA 3 region and was only weak in the dendritic layers of principal cells. Scale bar, $100 \mu \mathrm{m}$. 
unit was restricted to a population of multipolar cells, presumptive interneurons (Fig. 13). This pattern was seen at various postnatal ages and persisted into adulthood (Gao and Fritschy, 1994). Thus, in combination with our observations about the colocalization of the $\alpha 2$ - and $\beta 2,3$-subunits (Fig. $8 B$ ), these results suggest that the subunit composition of $\mathrm{GABA}_{A}$ receptors expressed by hippocampal pyramidal cells does not change during ontogeny, at least with respect to the subunits analyzed in this study.

\section{Restricted glial cell localization of $G A B A_{A}$-receptor subunits}

In sections processed for immunofluorescence staining and analyzed by confocal laser microscopy, no evidence was found for a localization of the $\alpha 1-, \alpha 2$-, or $\beta 2,3$-subunits in glial cells in telencephalon, diencephalon, and brainstem at any time point during postnatal development. In cerebellum, however, staining for the $\alpha 2$-subunit was transiently observed in Bergmann glial cells between P4 and P20, as reported elsewhere (Muller et al., 1994). Double-immunofluorescence staining with glial fibrillary acid protein (GFAP) confirmed that the $\alpha 2$-subunit-IR was localized in Bergmann glial cells (Muller et al., 1994). In all other brain regions examined, $\mathrm{GABA}_{\mathrm{A}}$-receptor subunits were never colocalized with the astrocytic markers $S-100 \beta$, vimentin, and GFAP in individual cells, as analyzed in double-immunofluorescence staining experiments (not shown), thus confirming the neuronal localization of $\mathrm{GABA}_{\mathrm{A}}$ receptors in developing brain.

\section{Area-specific maturation of $G A B A_{A}$-receptor subunits}

The topographical specificity of the changes in subunit-IR were most striking in cerebral cortex and in the somatosensory system. In neocortex, the maturation of the $\alpha 1-$ and $\alpha 2$-subunits was area- and layer-specific, thereby revealing the presumptive borders of certain cortical areas as early as $\mathrm{P} 0$. In particular, primary visual (Vl) and somatosensory (S1) areas exhibited a distinct $\alpha$ l-subunit-IR at birth, whereas intervening areas were largely unstained. During the first postnatal days, the $\alpha 1$-subunit staining increased in layers III-IV of SI and V1, clearly delineating these areas from adjacent cortical territories (Fig. 1). The specificity of the distribution was such, that in S1 the $\alpha 1$-subunit-IR revealed the organization of the mystacial barrel field by an intense staining of individual barrels (corresponding to single whiskers) between $\mathrm{P} 3$ and $\mathrm{P} 10$ (Fig. 14A). Thereafter, the increase in $\alpha 1$-subunit-IR throughout the cerebral cortex gradually blurred the delineation of individual areas and at P20, staining was uniform across cortical layers and areas (Fig. 1). By contrast to the $\alpha 1$-subunit, the $\alpha 2$-subunit-IR was intense and uniform across the cortical plate at P0 (Fig. 2). At P2, staining was confined to the outer half of cortex and at P4-P6, a prominent band was seen in layer IV (Fig. 2). During the second postnatal week, the $\alpha 2$-subunit-IR decreased in layer III of $\mathrm{Sl}$ and $\mathrm{V} 1$, thereby producing a pattern complementary to that scen for the $\alpha 1$-subunit (Fig. 15). After P14, the decrease in $\alpha 2$-subunit-IR was also apparent in the remaining areas, as well as in layer IV. The $\alpha 2$-subunit-IR did not disappear entirely from neocortex, and a moderate staining, largely confined to the supragranular layers, could be observed in sections from P20 (Fig. 2) and adult brain.

In subcortical relay stations of the somatosensory system (i.e., trigeminal sensory nucleus and ventrobasal complex of the thalamus), the staining pattern of the $\mathrm{GABA}_{\mathrm{A}}$-receptor subunits examined outlined transiently the somatotopic representation of the mystacial vibrissae. Thus, in the spinal trigeminal nucleus pars caudalis, neurons intensely stained for the $\alpha 1$-subunit formed cylindrical structures corresponding to the five rows of whiskers (Fig. 14B). This pattern could be observed between birth and P10, and disappeared thereafter, as the staining decreased. In the adult, only a few isolated $\alpha 1$-subunit-positive neurons were seen in the trigeminal complex. In the ventrobasal complex of the thalamus, barreloids, corresponding to individual rows of whiskers, were outlined by the $\alpha 2$-subunit-IR between P2 and P6, and thereafter by the $\alpha 1$-subunit staining, although the latter remained faint at least until P10 (Fig. 4). The $\beta 2,3$-subunits also exhibited transiently a modular distribution in the somatosensory system, though less distinct than that observed for the $\alpha 1$ and $\alpha 2$-subunits (not shown).

\section{Discussion}

The present results demonstrate that $\mathrm{GABA}_{\mathrm{A}}$ receptors present in neonatal and adult brain differ in subunit composition, as shown by the differential maturation of individual subunits. The expression of receptors containing the $\alpha 1$-subunit increases markedly throughout most of the brain during postnatal development, whereas receptors containing the $\alpha 2$-subunit disappear from many areas shortly after the onset of $\alpha 1$-subunit expression. The decrease in $\alpha 2$-subunit staining and its replacement by the $\alpha 1$-subunit occurs on the level of individual neurons, as revealed by confocal laser microscopy. Both types of receptors are associated with the $\beta 2,3$-subunits, which show a prominent and widespread expression at every age examined. Thus, the switch in the expression between the $\alpha 1$ - and $\alpha 2$ subunits may correspond to the existence of molecularly distinct $\mathrm{GABA}_{\mathrm{A}}$-receptor subtypes in perinatal and adult brain.

\section{Developmental switch in $G A B A_{A}$-receptor subtypes}

The changes in $\mathrm{GABA}_{\mathrm{A}}$-receptor subunit expression reported here are well supported by in situ hybridization histochemistry studies and Western blot analyses, which demonstrate a high expression of the $\alpha 2-, \alpha 3-, \alpha 5-, \beta 3-$, and $\gamma 2$-subunits in neonatal brain (Fuchs and Sieghart, 1989; Sato and Neale, 1989; Gambarana et al., 1990, 1991; Vitorica et al., 1990; MacLennan et al., 1991; McKernan et al., 1991a; Zhang et al., 1991, 1992; Araki et al., 1992; Laurie et al., 1992; Poulter et al., 1992, 1993). These studies also showed a postnatal increase in $\alpha 1$-subunit expression, indicating that the lack of $\alpha 1$-subunit-IR in neonatal brain reflects low levels of this subunit and is not due to a change in antigenicity during development. It is of notice that we detected a distinct $\alpha \mathrm{l}$-subunit staining at $\mathrm{PO}$ in regions, such as cerebral cortex, where only low mRNA signals have been reported (Gambarana et al., 1990, 1991; MacLennan et al., 1991; Poulter et al., 1992). This suggests that protein levels sufficient to be detected immunohistochemically are rapidly formed following the onset of mRNA expression. Similar observations in other brain regions, such as thalamus for example, indicate a close parallel between the onset of mRNA expression and protein formation. With its higher resolution on the cellular level as compared to in situ hybridization, immunohistochemistry appears thus as a sensitive tool for analyzing the maturation of $\mathrm{GABA}_{\mathrm{A}}$-receptor subunits in developing brain.

Neonatal brain contains high levels of functional $\mathrm{GABA}_{\mathrm{A}}$ receptors, as shown autoradiographically, immunohistochemically and biochemically (Candy and Martin, 1979; Schlumpf et al., 1983; Kellogg and Pleger, 1989; Huntley et al., 1990; Cobas et al., 1991; Fiszman et al., 1993) (see introductory remarks). Our results suggest that receptors containing the $\alpha 2$-subunit, 

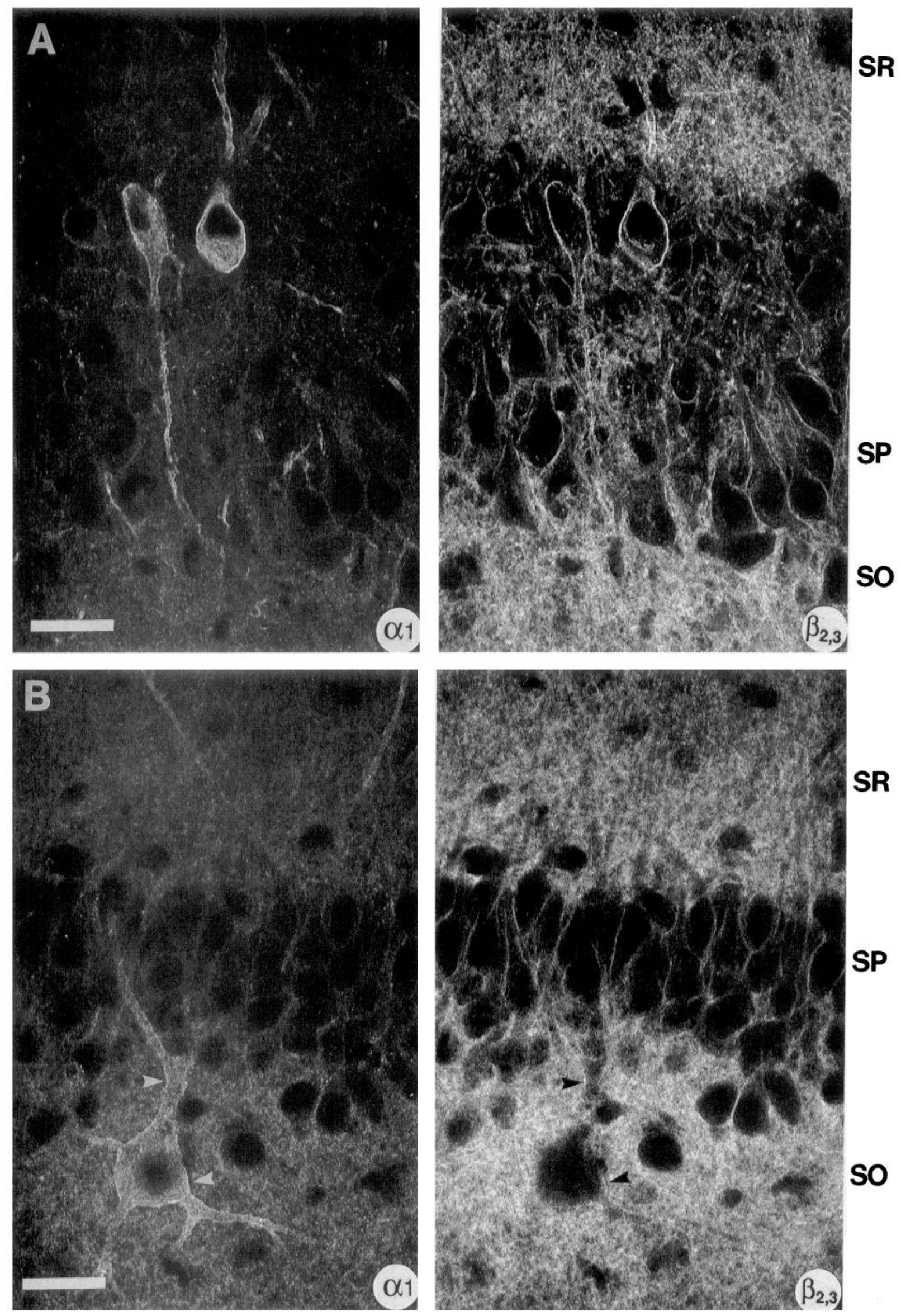
together with the $\beta 2$ - and/or $\beta 3$-subunits, are distributed on numerous neuron populations throughout the neonatal brain. Since neonatal receptors contain benzodiazepine binding sites (Schlumpf et al., 1983), they are also cxpected to contain the $\gamma 2$ - or $\gamma 3$-subunit (Pritchett et al., 1989b; Knoflach et al., 1991). Thus, the subunit combination $\alpha 2 / \beta 2,3 / \gamma 2$ may represent a preponderant $\mathrm{GABA}_{\mathrm{A}}$-receptor subtype expressed by most neurons in neonatal brain. This is in contrast to the adult brain, in which the subunit combination $\alpha 1 / \beta 2,3 / \gamma 2$ is the most prevalent, as shown biochemically on crude membrane preparations (Benke et al., 1991a,b). Therefore, the subunit composition of GABA receptors in adult brain is distinct from that in neonatal brain.

The changes in $\alpha 1$ - and $\alpha 2$-subunit-IR observed here during development strongly suggest a replacement of $\mathrm{GABA}_{\mathrm{A}}$ receptors containing the $\alpha 2$-subunit by receptors containing the $\alpha 1$ subunit in a majority of neurons. The transient colocalization of the $\alpha 1$ - and $\alpha 2$-subunits in neurons, which in the adult are devoid of $\alpha 2$-subunit staining, indicates that both receptor subtypes may be coexpressed within individual cells at early postnatal stages. Therefore, the gradual disappearance of the $\alpha 2$ subunit staining during development appears to be due to the downregulation of a receptor subtype, but cannot be attributed to neuron death. Staining for the $\alpha 2$-subunit remains intense in a few regions of adult brain, for example, striatum, hippocampus, superficial cortical layers and olfactory bulb granule cell layer. With the exception of cortex and hippocampus, these regions are largely devoid of $\alpha 1$-subunit and may therefore express receptors containing the $\alpha 2$-subunit in both perinatal and adult brain. However, since several other subunits (e.g., $\alpha 3, \alpha 5$, $\gamma 3$ ) are developmentally regulated (Laurie et al., 1992; Poulter et al., 1992, 1993), more complex alterations in the subunit composition of $\mathrm{GABA}_{\mathrm{A}}$-receptor subtypes may be expected to occur during ontogeny.

The developmental changes in the subunit composition of $\mathrm{GABA}_{\mathrm{A}}$ receptors demonstrated here are in line with pharmacological studies revealing a differential ontogeny of benzodiazepine type I and type II receptors (Candy and Martin, 1979; Lippa et al., 1981; Chisholm et al., 1983). The high abundance of BZ II receptors in perinatal brain reflects the prominent expression of receptors containing the $\alpha 2$-subunit, whereas the delayed appearance of BZ I sites (Lippa et al., 1981; Chisholm et al., 1983) corresponds well with the developmental pattern of receptors containing the $\alpha 1$-subunit. By showing that individual neurons express different types of $\mathrm{GABA}_{A}$ receptors during development, our results indicate that they may be differentially responsive to benzodiazepine receptor ligands at various stages of ontogeny.

Since bd- 17 recognizes both the $\beta 2$ - and $\beta 3$-subunits, the developmental maturation of these $\beta$-subunit proteins is not well defined. In particular, differential changes in the expression of the $\beta 2$ - and $\beta 3$-subunits, similar to those observed here for the $\alpha 1$ - and $\alpha 2$-subunits, may have been masked by the covisualization of these subunits with bd-17. In.situ hybridization studies provide no clarification on this point. While some re- ports described both $\beta 2$ - and $\beta 3$-subunit mRNAs highly expressed at birth in certain brain regions (Gambarana et al., 1991; Poulter et al., 1993), other studies observed a postnatal increase in $\beta 2$-subunit mRNA similar to that of the $\alpha 1$-subunit mRNA (Zhang et al., 1991; Laurie et al., 1992). Thus, bd-17 staining in neonatal brain may correspond mostly to the presence of the $\beta 3$-subunit.

\section{Significance of the transient expression of subunits}

Developmental alterations in the structure of $\mathrm{GABA}_{\mathrm{A}}$ receptors may affect their signal transduction properties to accommodate different functional properties. In view of the paucity of synapses in perinatal brain (Aghajanian and Bloom, 1967; Blue and Parnavelas, 1983b), the effects of GABA are expected to be mediated nonsynaptically, possibly through release from growth cones (Taylor and Gordon-Weeks, 1989; Taylor et al., 1990). GABA-induced currents in neonatal neurons show little desensitization (Cherubini et al., 1990), suggesting an enhancement of the effects of GABA relative to mature neurons. Therefore, $\mathrm{GABA}_{\mathrm{A}}$ receptors in neonatal brain may be characterized by a greater responsiveness to GABA as compared to those in the adult brain. In addition, GABA has been shown to exert an excitatory action in immature neurons, leading to $\mathrm{Ca}^{2+}$ influx via voltage-sensitive $\mathrm{Ca}^{2+}$ channels (Cherubini et al., 1991; Yuste and Katz, 1993). This excitatory action of GABA, which may underlie its postulated neurotrophic role (see Cherubini et al., 1991; Meier et al., 1991, for review), shifts gradually towards an inhibitory action, probably following a change in the $\mathrm{Cl}^{-}$ gradient across the plasma membrane. Our results are compatible with the hypothesis that these distinct roles of GABA are mediated by different receptor subtypes.

The prominent expression of the $\beta 2,3$-subunits during postnatal development indicates that these subunits are present to a similar extent in both perinatal and adult $\mathrm{GABA}_{\mathrm{A}}$ receptors. A recent study suggested that the $\beta$-subunits may be involved in the intracellular sorting of receptors, as evidenced for recombinant receptors transfected in cultured epithelial cells (PerezVelazquez and Angelides, 1993). It is therefore conceivable that the $\beta$-subunits are required for establishing the subcellular distribution of $\mathrm{GABA}_{\mathrm{A}}$ receptors in both developing and adult neurons. The transient staining for the $\beta 2,3$-subunits in certain regions, notably in the inferior olive, indicates that their expression may be adjusted during neuronal maturation. For instance, alterations in the expression of the $\beta 3$-subunit mRNA observed perinatally in the inferior olive have been suggested to correlate with the phase of refinement of synaptic connections between olivary neurons and cerebellar Purkinje cells (Frostholm et al., 1992).

The existence of distinct embryonic and adult types of receptors differing in subunit composition and functional properties has been demonstrated for other members of the ligand-gated ion channel family, such as the nicotinic ACh-receptor (Witzemann et al., 1987; Daubas et al., 1990) and the glycine-receptor (Betz, 1991; Malosio et al., 1991). For both receptor types, the

\footnotetext{
Figure 13. Partial colocalization of the $\alpha 1$ - and $\beta 2,3$-subunits in the hippocampus, as visualized by confocal laser microscopy in sections processed for double-immunofluorescence staining. $A$, in the CA3 area of a P6 rat, an intense $\beta 2,3$-subunit-IR decorated the soma and dendrites of both pyramidal cells and nonpyramidal cells. Colocalization with the $\alpha 1$-subunit was apparently restricted to nonpyramidal cells. $B$, In the CAl region (P14 rat), a similar pattern was apparent, although the intense $\beta 2,3$-subunit-IR largely masked the staining of the nonpyramidal cell (arrowheads). In addition, a faint $\alpha 1$-subunit-IR became visible in $S O$ and $S R$. Scale bars, $25 \mu \mathrm{m}$.
} 

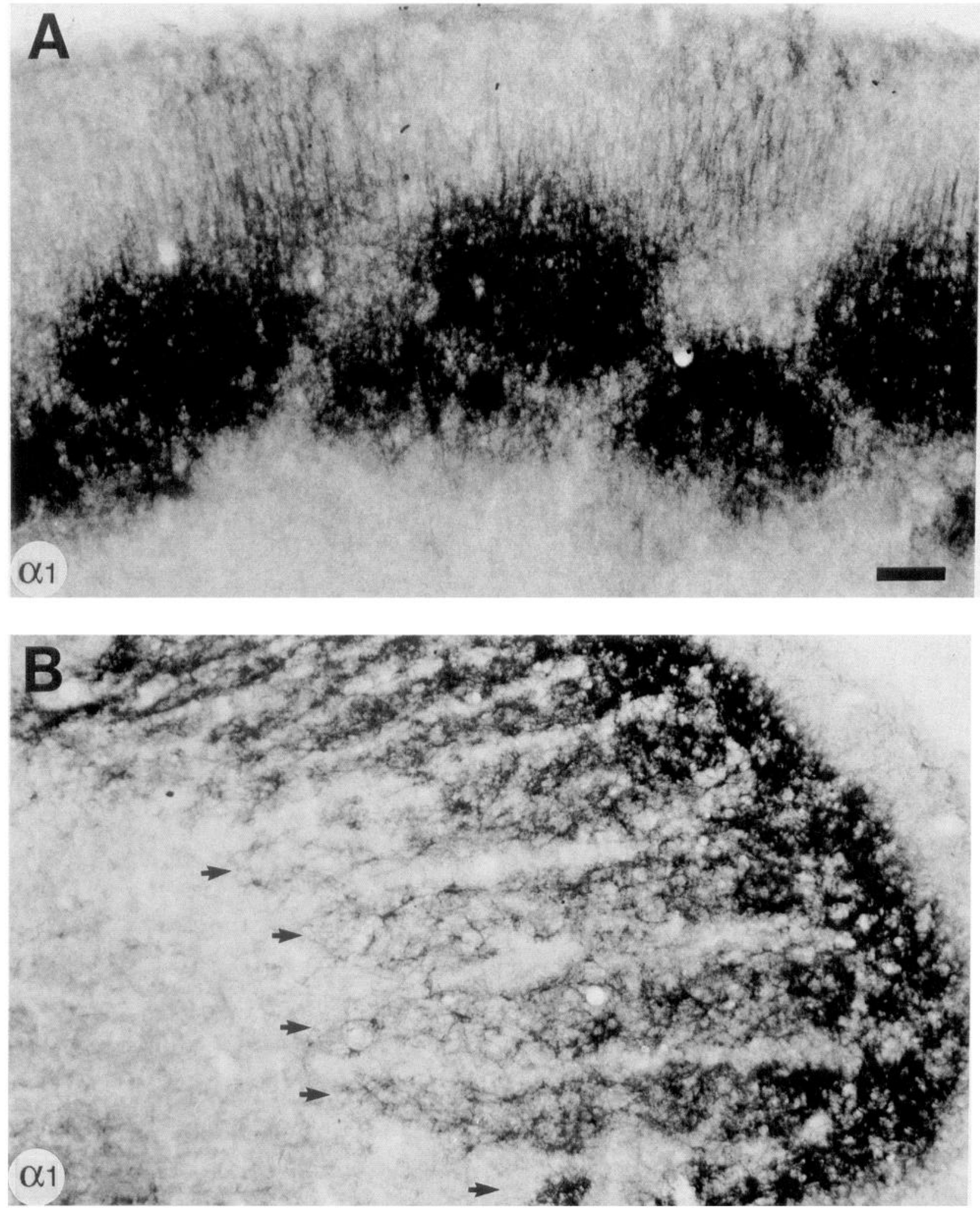

Figure 14. Somatotopic representation of the vibrissal sensory system, as visualized in parasagittal sections stained with the $\alpha 1$-subunit antiserum. $A$, In primary somatosensory cortex (barrel field) of a P4 rat, individual barrels were demarcated by a strong $\alpha 1$-subunit-IR. In each barrel, intensely stained neurons and their apical dendrites are visible. Three rows containing each two to three barrels are depicted in this picture, owing to the nearly tangential plane of the section. $B$, In the trigeminal spinal nucleus, pars caudalis (P4 rat), the vibrissal representation was evidenced by five cylindrical columns of intensely stained neurons (arrows), which correspond to the five rows of whiskers. The narrow columns seen in the upper third of the panel correspond to the facial representation. Immunoperoxidase staining. Scale bars, $100 \mu \mathrm{m}$. 

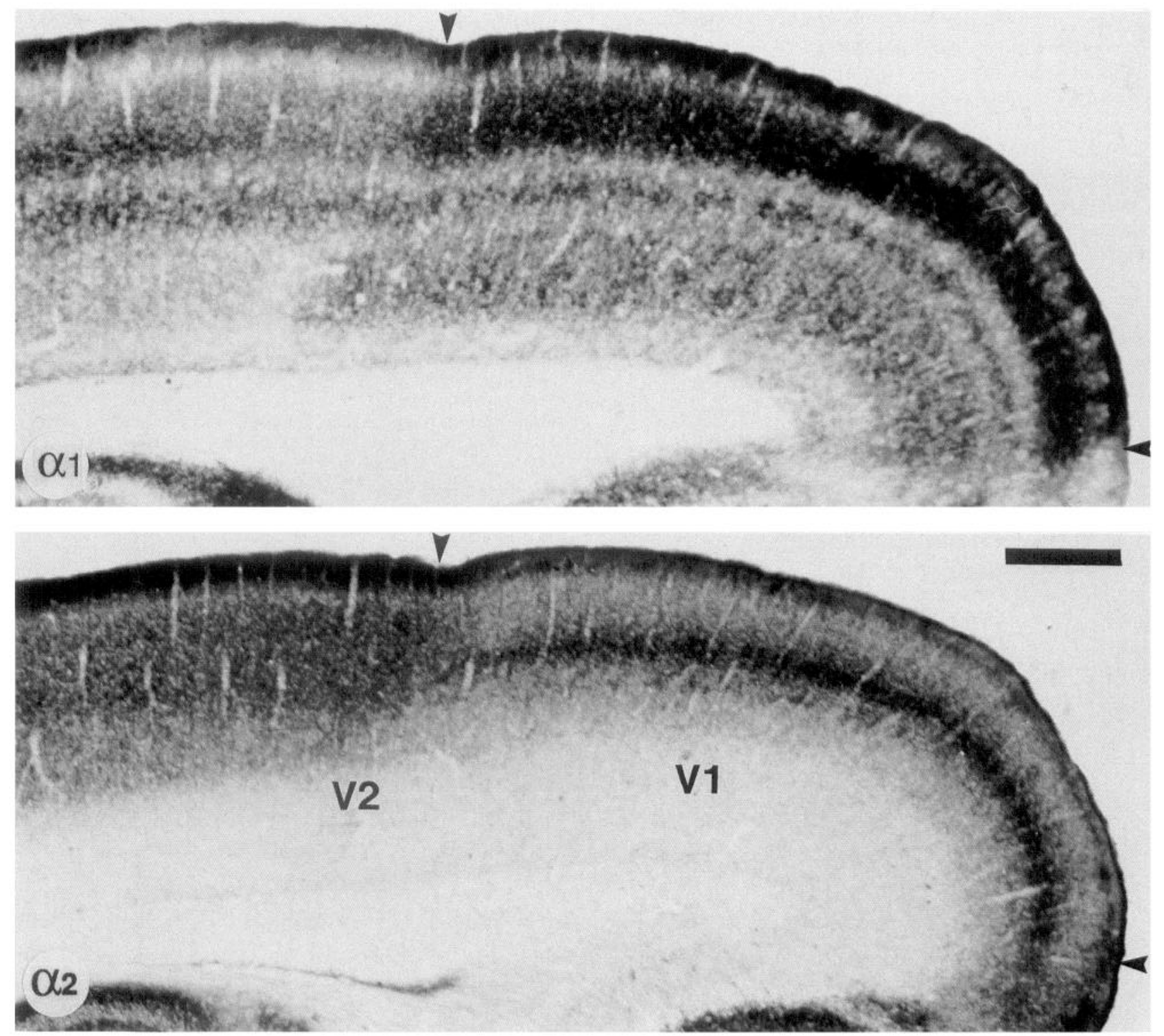

Figure 15. Complementary distribution of the $\alpha 1$ - and $\alpha 2$-subunit-IR in developing occipital cortex, as visualized by immunoperoxidase staining in a P10 rat. Whereas the strong $\alpha 1$-subunit-IR in layers III-IV of primary visual cortex $(V 1)$ delineated this region from lightly stained adjacent secondary visual areas (V2), the opposite pattern was seen for the $\alpha 2$-subunit-IR, which appeared more intense in layer III of $V 2$ than of $V 1$. Arrowheads mark the boundaries of V1. Scale bar, $0.5 \mathrm{~mm}$.

fetal and adult forms differ in channel kinetics, with a shortening of the open time in the adult receptor (Sakmann and Brenner, 1978; Takahashi et al., 1992). These observations raise the possibility that a similar developmental change takes place for the $\mathrm{GABA}_{\mathrm{A}}$ receptor. Furthermore, evidence is rapidly accumulating for a developmental regulation of the subunit composition of NMDA receptors in vivo (Carmignoto and Vicini, 1992; Burgard and Hablitz, 1993; Marti et al., 1993; Williams et al., 1993).

\section{$G A B A_{A}$-receptor maturation and onset of synaptic inhibitory transmission}

The developmental expression of the $\alpha 1$-subunit correlates well with the degree of maturation of individual neuron populations. For instance, $\alpha 1$-subunit expression in neonates is restricted to brain regions that differentiate prenatally, for example, brainstem and olfactory bulb. The $\alpha 1$-subunit may thus represent a hallmark of receptors engaged in synaptic functions and serve as a marker to study their development. As discussed above, the onset of $\alpha 1$-subunit expression corresponds to the appearance of a new $\mathrm{GABA}_{\mathrm{A}}$-receptor subtype in maturing brain. Furthermore, the disappearance of receptors containing the $\alpha 2$ subunit coincides with the period of synaptogenesis, indicating that the $\alpha 2$-subunit expression may be downregulated by inhibitory synaptic activity.

A major question is whether the maturation of synaptic GA$\mathrm{BA}_{\mathrm{A}}$ receptors precedes or follows the formation of inhibitory synapses. In their analysis of synaptogenesis in the granule cell layer of the cerebellum, Meinecke and Rakic (1990) concluded that $\mathrm{GABA}_{\mathrm{A}}$ receptors are expressed after the formation of synaptic connections from Golgi type II interneurons. By contrast, our data provide several examples in which the expression of $\mathrm{GABA}_{\mathrm{A}}$ receptors containing the $\alpha 1$-subunit precedes by several days the maturation of GABAergic presynaptic elements. For instance, the prominent $\alpha 1$-subunit staining in neurons of layer 
IV of somatosensory and primary visual cortex contrasts with the delayed appearance of GABA immunoreactive terminals in this layer (Del Rio et al., 1992). Similarly, Purkinje cells express the $\alpha 1$-subunit-IR early as P0, that is, several days before GABAergic connections from cerebellar interneurons are established (Altman, 1972a,b; McLaughlin et al., 1975). Therefore, the maturation of synaptic $\mathrm{GABA}_{\mathrm{A}}$ receptors may precede the formation of inhibitory synapses, at least in certain regions.

The area-specific upregulation of the $\alpha 1$-subunit-IR in neocortex, first seen in primary somatosensory and visual areas, does not correspond to the known rostral-caudal, medial-lateral gradients of cortical neurogenesis and synaptogenesis (Smart and Smart, 1982; Bayer and Altman, 1991; Voigt et al., 1993). Moreover, the upregulation of the $\alpha 1$-subunit-IR is first seen in the developing layers III-IV and does thus not follow the insideout pattern of layer generation and neuronal maturation of the cerebral cortex (Miller, 1986, 1988; Bayer and Altman, 1991). Rather, the early appearance of the $\alpha \mathrm{l}$-subunit-lK in primary sensory areas points to the existence of area-specific patterns of receptor maturation. These observations suggest that the formation of inhibitory circuits may be regulated independently in different cortical areas.

In addition to neocortex, area-specific changes in $\mathrm{GABA}_{\mathrm{A}}$ receptor subunit expression were also observed in striatum and in subcortical relay stations of the somatosensory system. This suggests that receptor maturation is coordinated among functionally related sets of neurons. The level of $\mathrm{GABA}_{\mathrm{A}}$-receptor expression between neighboring neurons may thus be regulated by activity-dependent mechanisms. Since a somatotopic distribution of $\mathrm{GABA}_{\mathrm{A}}$-receptor subunits is apparent in the somatosensory system as early as $\mathrm{P} 0$, a functional parcellation is likely to take place prenatally. In striatum the mosaic formed by the $\alpha 2-$ and $\beta 2,3$-subunits staining in neonatal brain is very similar to the striatal islands formed by dopaminergic afferent fibers (Olson et al., 1972), believed to reflect the patch and matrix compartmentalization of the striatum (Gerfen et al., 1987). This pattern may thus point to a differential maturation of $\mathrm{GABA}_{\mathrm{A}^{-}}$ receptor subunits in functionally distinct striatal compartments. These observations underscore the potential usefulness of GA$\mathrm{BA}_{\mathrm{A}}$-receptor subunit-IR to monitor the emergence of modular brain structures and to study mechanisms involved in the functional parcellation of neuronal systems during ontogeny.

\section{References}

Aghajanian GK, Bloom FE (1967) The formation of synaptic junctions in developing rat brain: a quantitative electron microscopic study. Brain Res 6:716-727.

Altman J (1972a) Postnatal development of the cerebellar cortex in the rat. I. The external germinal layer and the transitional molecular layer. J Comp Neurol 145:353-398.

Altman J (1972b) Postnatal development of the cerebellar cortex in the rat. II. Phases in the maturation of Purkinje cells and of the molecular layer. J Comp Neurol 145:399-464.

Araki T, Kiyama H, Tohyama M (1992) $\mathrm{GABA}_{\mathrm{A}}$ receptor subunit messenger RNAs show differential expression during cortical development in the rat brain. Neuroscience 51:583-591.

Barbin G, Pollard H, Gaiarsa JL, Ben-Ari Y (1993) Involvement of $\mathrm{GABA}_{\mathrm{A}}$ receptors in the outgrowth of cultured hippocampal neurons. Neurosci Lett 152:1150-1154.

Bayer SA, Altman J, eds (1991) Neocortical development. New York: Raven.

Behar T, Schaffner A, Laing P, Hudson L, Komoly S, Barker J (1993) Many spinal cord cells transiently express low molecular weight forms of glutamate acid decarboxylase during embryonic development. Dev Brain Res 72:203-218.
Belhage B, Hansen GH, Schousboe A (1990) GABA agonist induced changes in ultrastructure and GABA receptor expression in cerebellar granule cells is linked to hyperpolarization of the neurons. Int J Dev Neurosci 8:473-479.

Benke D, Mertens S, Mohler H (1991a) Ubiquitous presence of GA$\mathrm{BA}_{\mathrm{A}}$ receptors containing the $\alpha 1$-subunit in rat brain demonstrated by immunoprecipitation and immunohistochemistry. Mol Neuropharmacol 1:103-110.

Benke D, Mertens S, Trzeciak A, Gillessen D, Mohler H (1991b) GA$\mathrm{BA}_{\mathrm{A}}$ receptors display association of $\gamma 2$-subunit with $\alpha 1$ - and $\beta 2 / 3$ subunits. J Biol Chem 266:4478-4483.

Betz H (1991) Glycine receptors: heterogeneous and widespread in the mammalian brain. Trends Ncurosci 14:458-461.

Blue ME, Parnavelas JG (1983a) The formation and maturation of synapses in the visual cortex of the rat. II. Quantitative analysis. J Neurocytol 12:697-712.

Blue ME, Parnavelas JG (1983b) The formation and maturation of synapses in the visual cortex of the rat. II. Quantitative analysis. $J$ Neurocytol 12:697-712.

Burgard EC, Hablitz JJ (1993) Developmental changes in NMDA and non-NMDA receptor-mediated synaptic potentials in rat neocortex. J Neurophysiol 69:230-240.

Candy JM, Martin LL (1979) The postnatal development of the benzodiazepine receptor in the cerebral cortex and cerebellum of the rat. J Neurochem 32:655-658.

Carmignoto G, Vicini S (1992) Activity-dependent decrease in NMDA receptor responses during development of the visual cortex. Science 258:1007-1011.

Cherubini E, Rovira C, Gaiarsa JL, Corradetti R, Ben-Ari Y (1990) GABA mediated excitation in immature rat CA3 hippocampal neurons. Int J Dev Neurosci 8:481-490.

Cherubini E, Gaiarsa JL, Ben-Ari Y (1991) GABA: an excitatory transmitter in early postnatal life. Trends Neurosci 14:515-519.

Chisholm J, Kellogg C, Lippa A (1983) Development of benzodiazepine binding subtypes in three regions of rat brain. Brain Res 267: 388-391.

Chronwall B, Wolff JR (1980) Prenatal and postnatal development of GABA-accumulating cells in the occipital neocortex of rat. J Comp Neurol 190:187-208.

Cobas A, Fairen A, Alvarez-Bolado G, Sanchez MP (1991) Prenatal development of the intrinsic neurons of the rat neocortex: a comparative study of the distribution of GABA-immunoreactive cells and the GABA $_{A}$ receptor. Neuroscience 40:375-397.

Daubas P, Devillers-Thiery A, Geoffroy B, Martinez S, Bessis A, Changeux JP (1990) Differential expression of the neuronal acetylcholine receptor $\alpha 2$ subunit gene during chick brain development. Neuron 5:49-60.

Del Rio JA, Soriano E, Ferrer I (1992) Development of GABA-immunoreactivity in the neocortex of the mouse. J Comp Neurol 326: 501-526.

Doble A, Martin IL (1992) Multiple benzodiazepine receptors: no reason for anxiety. Trends Pharmacol Sci 13:76-81.

Ewert M, Shivers BD, Luddens H, Mohler H, Seeburg PH (1990) Subunit selectivity and epitope characterization of mAbs directed against the $\mathrm{GABA}_{\mathrm{A}}$ /benzodiazepine receptor. J Cell Biol 110:20432048.

Fiszman ML, Novotny EA, Lange GD, Barker JL (1990) Embryonic and early postnatal hippocampal cells respond to nanomolar concentrations of muscimol. Dev Brain Res 53:186-193.

Fiszman ML, Behar T, Lange GD, Smith SV, Novotny EA, Barker JL (1993) GABAergic cells and signals appear together in the early postmitotic period of telencephalic and striatal development. Dev Brain Res 73:243-251.

Fritschy JM, Benke D, Mertens S, Oertel WH, Bachi T, Mohler H (1992) Five subtypes of type A $\gamma$-aminobutyric acid receptors identified in neurons by double and triple immunofluorescence staining with subunit-specific antibodies. Proc Natl Acad Sci USA 89:67266730.

Frostholm A, Zdilar D, Luntz-Leybman V, Janapati V, Rotter A (1992) Ontogeny of $\mathrm{GABA}_{\mathrm{A}}$-benzodiazepine receptor subunit $\mathrm{mRNAs}$ in the murine inferior olive: transient appearance of $\beta 3$ subunit $\mathrm{mRNA}$ and $\left[{ }^{3} \mathrm{H}\right]$ muscimol binding sites. Mol Brain Res 16:246-254.

Fuchs K, Sieghart W (1989) Evidence for the existence of several different $\alpha$ - and $\beta$-subunits of the GABA/benzodiazepine receptor complex from rat brain. Neurosci Lett 97:329-333. 
Gambarana C, Pittman R, Siegel RE (1990) Developmental expres-

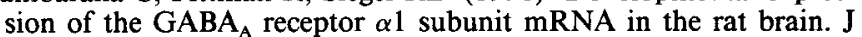
Neurobiol 21:1169-1179.

Gambarana C, Beattie CE, Rodriguez ZR, Siegel RE (1991) Regionspecific expression of messenger RNAs encoding $\mathrm{GABA}_{\mathrm{A}}$ receptor subunits in the developing rat brain. Neuroscience 45:423-432.

Gao B, Fritschy JM (1994) Selective allocation of GABA Areceptors containing the $\alpha 1$-subunit to neurochemically distinct subpopulations of rat hippocampal interneurons. Eur J Neurosci, in press.

Gao B, Fritschy JM, Benke D, Mohler H (1993) Neuron-specific expression of $\mathrm{GABA}_{\mathrm{A}}$-receptor subtypes: differential associations of the $\alpha 1$ - and $\alpha 3$-subunits with serotonergic and GABAergic neurons. Neuroscience 54:881-892.

Gerfen CR, Baimbridge KG, Thibault J (1987) The neostriatal mosaic. III. Biochemical and developmental dissociation of patch-matrix mesostriatal systems. J Neurosci 7:3935-3944.

Hsu SM, Raine L, Fanger H (1981) Use of avidin-biotin-peroxidase complex $(A B C)$ in immunoperoxidase techniques: a comparison between $\mathrm{ABC}$ and unlabeled antibody (PAP) procedures. J Histochem Cytochem 29:577-580.

Huntley GW, De Blas AL, Jones EG (1990) GABA A receptor immunoreactivity in adult and developing monkey sensory-motor cortex. Exp Brain Res 82:519-535.

Kageyama G, Robertson RT (1993) Development of geniculocortical projections to visual cortex in rat: evidence for early ingrowth and synaptogenesis. J Comp Neurol 335:123-148.

Kellogg CK, Pleger GL (1989) GABA-stimulated chloride uptake and enhancement by diazepam in synaptoneurosomes from rat brain during prenatal and postnatal development. Dev Brain Res 49:87-95.

Knoflach F, Rhyner T, Villa M, Kellenberger S, Drescher U, Malherbe P, Sigel E, Mohler H (1991) The $\gamma 3$-subunit of the GABA -receptor $^{-}$ confers sensitivity to benzodiazepine receptor ligands. FEBS Lett 293: 191-194.

Lauder JM, Han VKM, Henderson P, Verdoorn T, Towle AC (1986) Prenatal ontogeny of the GABAergic system in the rat brain: an immunocytochemical study. Neuroscience 19:465-493.

Laurie DJ, Wisden W, Seeburg PH (1992) The distribution of thirteen $\mathrm{GABA}_{\mathrm{A}}$ receptor subunit mRNAs in the rat brain. III. Embryonic and postnatal development. J Neurosci 12:4151-4172.

Lippa AS, Beer B, Sano MC, Vogel RA, Meyerson LR (1981) Differential ontogeny of type 1 and type 2 benzodiazepine receptors. Life Sci 28:2343-2347.

Ma W, Behar T, Barker JL (1992) Transient expression of GABA immunoreactivity in the developing rat spinal cord. J Comp Neurol 235:271-290.

MacLennan AJ, Brecha N, Khrestchatisky M, Sternini C, Tillakaratne NJK, Chiang MY, Anderson K, Lai M, Tobin AJ (1991) Independent cellular and ontogenetic expression of mRNAs encoding three a polypcptides of the rat $\mathrm{GABA}_{\mathrm{A}}$ receptor. Neuroscience 43:369-380.

Malosio ML, Marqueze-Pouey B, Kuhse J, Betz H (1991) Widespread expression of glycine receptor subunit mRNAs in the adult and developing rat brain. EMBO J 10:2401-2409.

Marksitzer R, Benke D, Fritschy JM, Mohler H (1993) GABA Are- $^{-}$ ceptors: drug binding profile and distribution of receptors containing the $\alpha 2$-subunit in situ. J Recept Res 13:467-477.

Marti T, Benke D, Mertens S, Heckendorn R, Pozza M, Allgeier H, Angst C, Laurie D, Seeburg P, Mohler H (1993) Molecular distinction of three $N$-methyl-D-aspartate-receptor subtypes in situ and developmental receptor maturation demonstrated with the photoaffinity ligand ${ }^{25}$ I-labeled CGP 55802A. Proc Natl Acad Sci USA 90:84348438 .

Mckernan RM, Cox P, Whiting P (1991a) Differential expression of $\mathrm{GABA}_{\mathrm{A}}$ rcceptor $\alpha$-subunits in rat brain during development. FEBS Lett 286:44-46.

McKernan RM, Quirk K, Prince R, Cox PA, Gillard NP, Ragan CI, Whiting $P$ (1991b) GABA receptor subtypes immunopurified from $\alpha$ rat brain with a subunit-specific antibodies have unique pharmacological properties. Neuron 7:667-676.

McLaughlin BJ, Wood JG, Saito K, Roberts E, Wu JY (1975) The fine structural localization of glutamate decarboxylase in developing axonal processes and presynaptic terminals of rodent cerebellum. Brain Res 85:355-371.

Meier E, Jorgensen OS (1986) $\gamma$-Aminobutyric acid affects the developmental expression of neuron-associated proteins in cerebellar granule cell cultures. J Neurochem 46:1256-1262.
Meier E, Jorgensen OS, Schousboe A (1987) Effect of repeated treatment with a $\gamma$-aminobutyric acid receptor agonist on postnatal neural development in rats. J Neurochem 49:1462-1470.

Meier E, Hertz L, Schousboe A (1991) Neurotransmitters as developmental signals. Neurochem Int 19:1-15.

Meinecke DL, Rakic P (1990) Developmental expression of GABA and subunits of the $\mathrm{GABA}_{\mathrm{A}}$ receptor complex in an inhibitory synaptic circuit in the rat cerebellum. Dev Brain Res 55:73-86.

Meinecke DL, Rakic P (1992) Expression of GABA and GABA ceptors by neurons of the subplate zone in developing primate occipital cortex: evidence for transient local circuits. J Comp Neurol 317:91-101.

Miller MW (1986) Maturation of rat visual cortex. III. Postnatal morphogenesis and synaptogenesis of local circuit neurons. Dev Brain Res 25:271-285.

Miller MW (1988) Development of projection and local circuit neurons in neocortex. In: Cerebral cortex, Vol 7, Development and maturation of cerebral cortex (Peters A, Jones EG, eds), pp 133-176. New York: Plenum.

Mohler H, Malherbe P, Draguhn A, Richards JG (1990) GABA $_{A}$ receptors: structural requirements and sites of gene expression in mammalian brain. Neurochem Res 15:199-207.

Mohler H, Benke D, Mertens S, Fritschy JM (1992) GABA $_{A}$-receptor subtypes differing in $\alpha$-subunit composition display unique pharmacological profiles. In: GABAergic synaptic transmission (Biggio $G$ Concas A, Costa E, eds), pp 41-53. New York: Raven.

Muller T, Fritschy JM, Grosche J, Pratt GD, Mohler H, Kettenmann H (1994) Developmental regulation of voltage-gated $\mathrm{K}^{+}$-channel and $\mathrm{GABA}_{\mathrm{A}}$-receptor expression in Bergmann glial cells. J Neurosci 14:2503-2514.

Olsen RW, Tobin AJ (1990) Molecular biology of GABA A $_{A}$ receptors. FASEB J 4:1469-1480.

Olson L, Seiger A, Fuxe K (1972) Heterogeneity of striatal and limbic dopamine innervation: highly fluorescent islands in developing and adult rats. Brain Res 44:283-288.

Perez-Velazquez JL, Angelides KJ (1993) Assembly of GABA $A_{A}$ receptor subunit determines sorting and localization in polarized cells. Nature 361:457-459.

Poulter MO, Barker JL, O'Carroll AM, Lolait SJ, Mahan LC (1992) Differential and transient expression of $\mathrm{GABA}_{\mathrm{A}}$ receptor $\alpha$-subunit mRNAs in the developing rat CNS. J Neurosci 12:2888-2900.

Poulter MO, Barker JL, O'Carroll AM, Lolait SJ, Mahan LC (1993) Co-existent expression of $\mathrm{GABA}_{\mathrm{A}}$ receptor $\beta 2, \beta 3$ and $\gamma 2$ subunit messenger RNAs during embryogenesis and early postnatal development of the rat central nervous system. Neuroscience 53:10191033.

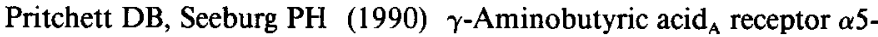
subunit creates novel type II benzodiazepine receptor pharmacology. J Neurochem 54:1802-1804.

Pritchett DB, Luddens H, Seeburg PH (1989a) Type I and type II $\mathrm{GABA}_{\mathrm{A}}$-benzodiazepine receptors produced in transfected cells. Science 245:1389-1392.

Pritchett DB, Sontheimer H, Shivers BD, Ymer S, Kettenmann H, Schofield PR, Seeburg PH (1989b) Importance of a novel GABA receptor subunit for benzodiazepine pharmacology. Nature 338:582585.

Richards JG, Schoch P, Haring P, Takacs B, Mohler H (1987) Resolving $\mathrm{GABA}_{\mathrm{A}}$ /benzodiazepine receptors: cellular and subcellular localization in the CNS with monoclonal antibodies. $\mathrm{J}$ Neurosci 7:1866-1886.

Sakmann B, Brenner HR (1978) Change in synaptic channel gating during neuromuscular development. Nature 276:401-402.

Sato TN, Neale JH (1989) Immunological identification of multiple $\alpha$-like subunits of the $\gamma$-aminobutyric acid receptor complex purified from neonatal rat cortex. J Neurochem 53:1089-1095.

Schlumpf M, Richards JG, Lichtensteiger W, Mohler H (1983) An autoradiographic study of the prenatal development of benzodiazepine-binding sites in rat brain. J Neurosci 3:1478-1487.

Schoch P, Richards JG, Haring $P$, Takacs B, Stahli C, Staehelin T, Haefely W, Mohler H (1985) Co-localization of $\mathrm{GABA}_{\mathrm{A}}$ receptors and benzodiazepine receptors in the brain shown by monoclonal antibodies. Nature 314:168-171.

Seeburg PH, Wisden W, Verdoorn TA, Pritchett DB, Werner P, Herb A, Luddens H, Sprengel R, Sakmann B (1990) The GABA $A_{A}$ receptor 
family: molecular and functional diversity. Cold Spring Harbor Symp Quant Biol 55:29-39.

Shaw C, Cameron L, March D, Cynader M, Zielinski B, Hendrickson A (1991) Pre- and postnatal development of GABA receptors in Macaca monkey visual cortex. J Neurosci 11:3943-3959.

Smart IHM, Smart M (1982) Growth patterns in the lateral wall of the mouse telencephalon. 1. Autoradiographic studies of the histogenesis of the isocortex and adjacent areas. J Anat 134:273-298.

Somogyi P, Takagi H (1982) A note on the use of picric acid-paraformaldehyde-glutaraldehyde fixative for correlated light and electron microscopic immunocytochemistry. Neuroscience 7:1779-1783.

Spoerri PE (1988) Neurotrophic effects of GABA in cultures of embryonic chick brain and retina. Synapse 2:11-22.

Takahashi T, Momiyama A, Hirai K, Hishinuma F, Akagi H (1992) Functional correlation of fetal and adult forms of glycine receptors with developmental changes in inhibitory synaptic receptor channels. Neuron 9:1155-1161.

Taylor J, Gordon-Weeks PR (1989) Developmental changes in the calcium dependency of $\gamma$-aminobutyric acid release from isolated growth cones: correlation with growth cone morphology. J Neurochem 53:834-843.

Taylor J, Docherty M, Gordon-Weeks PR (1990) GABAergic growth cones: release of endogenous $\gamma$-aminobutyric acid precedes the expression of synaptic vesicle antigens. J Neurochem 54:1689-1699.

Van Eden CG, Mrzljak L, Voorn P, Uylings HBM (1989) Prenatal development of GABA-ergic neurons in the neocortex of the rat. $J$ Comp Neurol 289:213-227.
Vitorica J, Park D, Chin G, de Blas A (1990) Characterization with antibodies of the $\gamma$-aminobutyric acid $/$ /benzodiazepine receptor complex during development of the rat brain. J Neurochem 54:187-194.

Voigt T, De Lima AD, Beckmann M (1993) Synaptophysin immunohistochemistry reveals inside-out pattern of early synaptogenesis in ferret cerebral cortex. J Comp Neurol 330:48-64.

Williams K, Russell SL, Shen YM, Molinoff PB (1993) Developmental switch in the expression of NMDA receptors occurs in vivo and in vitro. Neuron 10:267-278.

Witzemann V, Barg B, Nishikawa Y, Sakmann B, Numa S (1987) Differential regulation of muscle acetylcholine receptor $\gamma$ and $\epsilon$-subunit mRNAs. FEBS Lett 223:104-112.

Yuste R, Katz LC (1993) Control of postsynaptic $\mathrm{Ca}^{2+}$ influx in developing neocortex by excitatory and inhibitory neurotransmitters. Neuron 6:333-344.

Zezula J, Sieghart W (1991) Isolation of type I and type II GABA - $^{-}$ benzodiazepine receptors by immunoaffinity chromatography. FEBS Lett 284:15-18.

Zhang JH, Sato M, Tohyama M (1991) Different postnatal development profiles of neurons containing distinct $\mathrm{GABA}_{\mathrm{A}}$ receptor $\beta$ subunit mRNAs $(\beta 1, \beta 2$, and $\beta 3)$ in the rat forebrain. J Comp Neurol 308:586-613.

Zhang JH, Sato M, Araki T, Tohyama M (1992) Postnatal ontogenesis of neurons containing GABA $\alpha 1$ subunit mRNA in the rat forebrain. Mol Brain Res 16:193-203. 